\title{
Tertiary deformation and metamorphism SE of Tibet: The folded Tiger-leap décollement of NW Yunnan, China
}

\author{
Robin Lacassin, ${ }^{1}$ Urs Schärer, ${ }^{2}$ P. Hervé Leloup, ${ }^{1}$ Nicolas Arnaud, ${ }^{3}$ \\ Paul Tapponnier, ${ }^{1}$ Xiaohan Liu, ${ }^{4}$ and Liansheng Zhang ${ }^{2}$
}

\begin{abstract}
The Yulong-Haba Xue Shan range, in the northwestern part of Yunnan (China), is a large N-S antiform that folds the Paleozoic series of the Yangzi platform. The upper Yangzi River (Jinsha Jiang) has cut a $3500 \mathrm{~m}$-deep valley (Hu Tiao gorge) across this antiform, thus exposing folded, bedding-parallel, ductile shear zones (décollements), with transport toward the SSW (in the present geographical coordinates). The large finite shear strain implies tens of kilometers of transport, pointing to the regional significance of these décollements. $\mathrm{Rb} / \mathrm{Sr}$ radiometric dating of phlogopites that crystallized in marbles within the foliation planes yields the age of the metamorphic and deformation event (35.9 \pm 0.3 $(2 \sigma) \mathrm{Ma})$. The age derives from an internal $\mathrm{Rb}-\mathrm{Sr}$ isochron, made on different size fractions of the same mineral, which provides a novel demonstration of the feasibility of such plots. Transport on the décollement and related shortening occurred prior to, or at the onset of, extrusion of Indochina along the Ailao Shan-Red River shear zone, $\approx 80 \mathrm{~km}$ west of the Yulong Shan. The ${ }^{39} \mathrm{Ar} /{ }^{40} \mathrm{Ar}$ age spectra of $\mathrm{K}$-feldspar from the core of the Yulong Shan suggest uplift by antiformal folding around 17 $\mathrm{Ma}$, as Indochina's extrusion came to an end. We infer that other large-scale Cenozoic décollements such as that exhumed in the Yulong Shan underlie some of the vast, folded areas that surround the eastern Himalayan syntaxis. Transport on such décollements, first toward the south and then toward the east, and folding above them, might have occurred during two principal shortening phases, whose ages bracket Indochina's escape toward the SE.
\end{abstract}

\section{Introduction}

During the $\approx 50-\mathrm{Myr}$ time span of India's collision with Asia, the convergence between the two continents has been absorbed both by crustal thickening on large-scale thrusts and by the lateral extrusion of continent-size blocks along great strike-slip faults [Tapponnier et al, 1986; Peltzer and

\footnotetext{
1 Laboratoire de Tectonique, Mécanique de la Lithosphère, URA 1093 CNRS, Institut de Physique du Globe de Paris, Paris, France.

2 Laboratoire de Géochronologie, URA 1093 CNRS, Université Paris 7 and Institut de Physique du Globe de Paris, Paris, France.

3 URA 10 CNRS, Magmas et Volcans, Université de ClermontFerrand, Clermont-Ferrand, France.

4 Academia Sinica, Beijing, China.

Copyright 1996 by the American Geophysical Union.

Paper number 95TC03749.

0278-7407/96/95TC-03749\$12.00
}

Tapponnier, 1988; Armijo et al., 1989]. While the proportions of shortening absorbed by either mechanism are still debated [e.g., England and Houseman, 1986; Tapponnier et al., 1986; England and Molnar, 1990; Le Pichon et al., 1992; Avouac and Tapponnier, 1993; Leloup et al, 1995], the idea that India's penetration into Asia induced extrusion of Indochina toward the SE [Tapponnier et al., 1986; Tapponnier et al. 1990a]. prior to that, which is presently underway, of Tibet and South China [Armijo et al., 1989; Avouac and Tapponnier, 1993], is now supported by abundant geological and geochronological evidence [Tapponnier et ah, 1990a; Leloup, 1991; Lacassin et al., 1993; Yang Zhenyu and Besse, 1993; Leloup et al., 1995; Yang Zhenyu et al., 1995]. Such field evidence, which rests firmly on accurate $\mathrm{U} / \mathrm{Pb}$ and ${ }^{39} \mathrm{Ar} /{ }^{40} \mathrm{Ar}$ radiometric dating [Schärer et al., 1990; Harrison et al., 1992; Leloup et al., 1993; Schairer et al., 1994], implies that a large amount of sinistral motion took place on the Ailao Shan-Red River shear zone, the main tectonic boundary between Indochina and South China, between the upper Eocene and the Miocene (35-17 Ma). Much less is known, however, about Tertiary deformation within regions north and south of that zone. How much shortening affected the crust of these regions, when, and how it was related to strike-slip motion remain to be assessed. As a step toward unraveling the kinematics, timing, and amount of Cenozoic shortening in the area surrounding the eastern Himalayan syntaxis, we present here the results of a structural study of polyphase shortening within the Yulong Shan range (northwestern Yunnan), combined with radiometric dating of greenschist metamorphism in the core of that range.

\section{Geology and Structure of the Yulong Shan Antiform}

\subsection{Brief Summary of the Geology of NW Yunnan}

Yunnan province (China) is cut by the Ailao Shan-Red River shear zone, which extends $\approx 1000 \mathrm{~km}$ from eastern Tibet to the South China Sea (Figure 1a). The narrow belt of highgrade mylonitic gneisses exposed along that zone, in the Xuelong Shan, Diancang Shan, Ailao Shan, and Day Nui Con Voi, provides outstanding evidence for ductile sinistral shear, testifying to the southeastward extrusion of Indochina [Tapponnier et al., 1990a; Leloup, 1991; Lacassin et al., 1993; Leloup et al., 1995]. The finite offset along the zone appears to be of the order of $700 \pm 200 \mathrm{~km}$ [Briais et al., 1993; Leloup et al. , 1995]. U/Pb ages obtained on variably deformed anatectic melts imply that sinistral shear under crustal melting conditions took place from at least 35 to $22 \mathrm{Ma}$ [Schärer et al., 1990; Schärer et al., 1994]. Modeling of ${ }^{39} \mathrm{Ar} /{ }^{40} \mathrm{Ar}$ outgassing patterns of K-feldspar further implies that transtensive uplift 


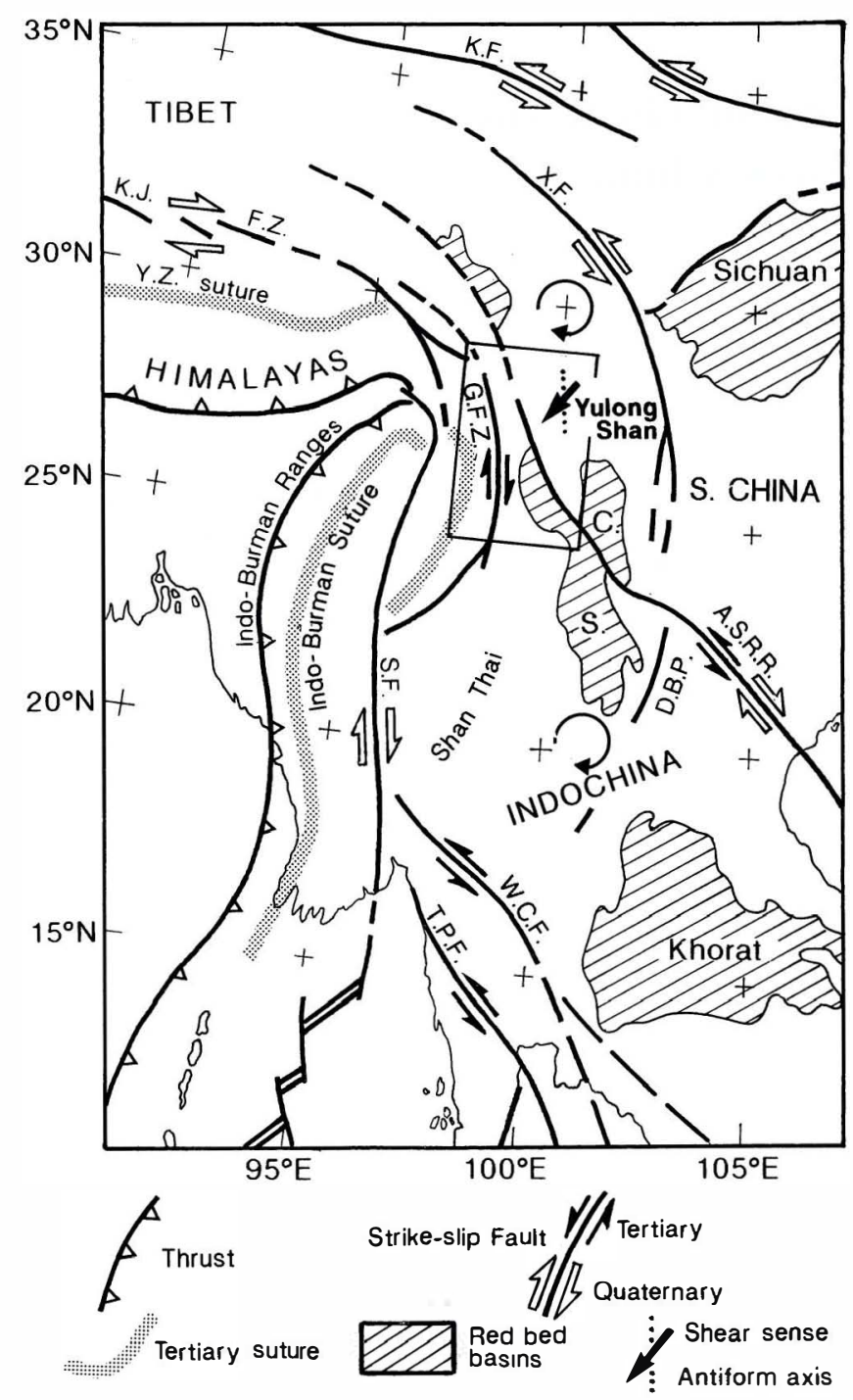

Figure 1a. Map of major Cenozoic structures around eastern Himalayan syntaxis. Abbreviations are K.F., Kunlun Fault; X.F., Xianshuihe Fault; K.J.F.Z., Karakorum-Jiali Fault zone; Y.Z., Yalong Zangbo; S.F., Sagaing Fault; A.S.R.R., AilaoShan Red River shear zone; G.F.Z., Gaoligong Fault zone; W.C.F., Wang Chao Fault; T.P.F., Three Pagodas Fault; D.B.P., Dien Bien Phu Fault; C., Chuxiong basin; S., Simao basin. Curved arrows indicate clockwise sense of rotation of blocks between strike-slip faults, inferred from paleomagnetic studies (see discussion in text). Box shows area of Figure lb.

accompanied sinistral motion till about $17 \mathrm{Ma}$ [Harrison et al., 1992; Leloup et al., 1994; Harrison et al., 1995]. Evidence of motion along the fault zone between $\approx 17$ and $5 \mathrm{Ma}$ is scarce and inconclusive. Around $5 \mathrm{Ma}$, however [Leloup et al., 1993], the sense of shear appears to have reversed to right lateral [Tapponnier and Molnar, 1977; Allen et al., 1984], a result of South China's extrusion by India's greater penetration into the interior of Asia [Tapponnier et al., 1986; Armijo et al., 1989]. Such motion is still underway, and much of Yunnan province is currently affected by ENE extension and NNW shortening, as attested by widespread active strike-slip and normal faultng [Tapponnier and Molnar, 1977; Allen et al., 1984; Leloup, 1991; Leloup et al. , 1995].

North and south of the Red River, the Chuxiong and Simao basins (Figure 1a) are filled by thick sequences (up to $6 \mathrm{~km}$ ) of Upper Triassic to lower Tertiary red beds [Geological Bureau of Yunnan Province, 1979; Bureau of Geology and Mineral Resources of Yunnan, 1983]. The red beds are folded by NW to NNW trending anticlines, implying NE to ENE directed Tertiary shortening, compatible with left-lateral movement on the Ailao Shan-Red River zone [Tapponnier et al. , 1990a; Leloup et al., 1995]. In the Chuxiong basin, the anticlines have generally steep axial planes, with similarly steep cleavage in their cores. In the southern part of this basin, near the Ailao Shan-Red River zone, this cleavage becomes stronger and, together with the fold axes, bends counterclockwise to parallel the foliation in the Ailao Shan mylonites, suggesting that folding and left-lateral shear were coeval, at least in part [Tapponnier et al., 1990a; Leloup et al., 1995].

NW of the Chuxiong basin, both the average elevation and relief increase as one approaches Tibet and the eastern Himalayan syntaxis, located less than $\approx 500 \mathrm{~km}$ farther west (Figure la). There, the NW trending Ailao Shan-Red River zone merges with long and narrow tectonic belts bounded by roughly N-S faults (Figure 1b). These belts, along which strike-slip motion probably took place in the Cenozoic, channel the Jinsha, Lancang, and Nu Jiang (Yangzi, Mekong, and Salween Rivers, respectively). East of them, between the Cheng Hai and Jianchuan faults (Figure 1b), the Lijiang Mountains expose strongly folded, faulted, and uplifted MidPaleozoic to Triassic rocks [Geological Bureau of Yunnan Province, 1979; Bureau of Geology and Mineral Resources of Yunnan, 1983; Wang and Chu, 1988]. These rocks, which belong to the cover of the Yangzi platform, comprise clastic deposits and shallow water carbonates with interbedded basalts. Most of the basalts are of mid-upper Permian age. The highest range of the area, NW of Lijiang, is the Yulong Shan, site of the present study (Figure $1 \mathrm{~b}$ and 2 ).

\subsection{Structure of the Yulong Shan Massif}

The Yulong Shan ("Jade Dragon Mountain") is a $\approx 20-\mathrm{km}$ wide, $=50-\mathrm{km}$-long range with sharp $\mathrm{N}-\mathrm{S}$ crests, marked by pinnacles culminating at 4500 to $5600 \mathrm{~m}$. The surrounding country has an average elevation of $\approx 3000 \mathrm{~m}$ (Figures 3 and 4). The highest summits are the Yulong Xue Shan (5595 m) and the Haba Xue Shan $(5396 \mathrm{~m})$ south and north of the Jinsha Jiang, respectively (Figures 2, 3, and 4).

The Yulong Shan is bounded to the east by steeply dipping Quaternary faults that are clear on aerial photographs, on the topographic maps and digital elevation model (DEM), and in the field (Figures 3 and 4). Some of the historical and instrumental earthquakes recorded in the region [Gu Gongxu et al., 1989] may be related to slip on those faults. Between Lijiang and Daju, the faults appear to be mostly normal and strike roughly $\mathrm{N}-\mathrm{S}$ (Figure 3 ). The main fault dips east and limits the steep, 1000- to 2000-m-high eastern flank of the range (Figure 4). About $15 \mathrm{~km}$ north of Lijiang, several east or west facing normal fault scarps cut the ancient moraines of glaciers flowing down from the Yulong Shan (letters $a$ and $b$ on Figure 


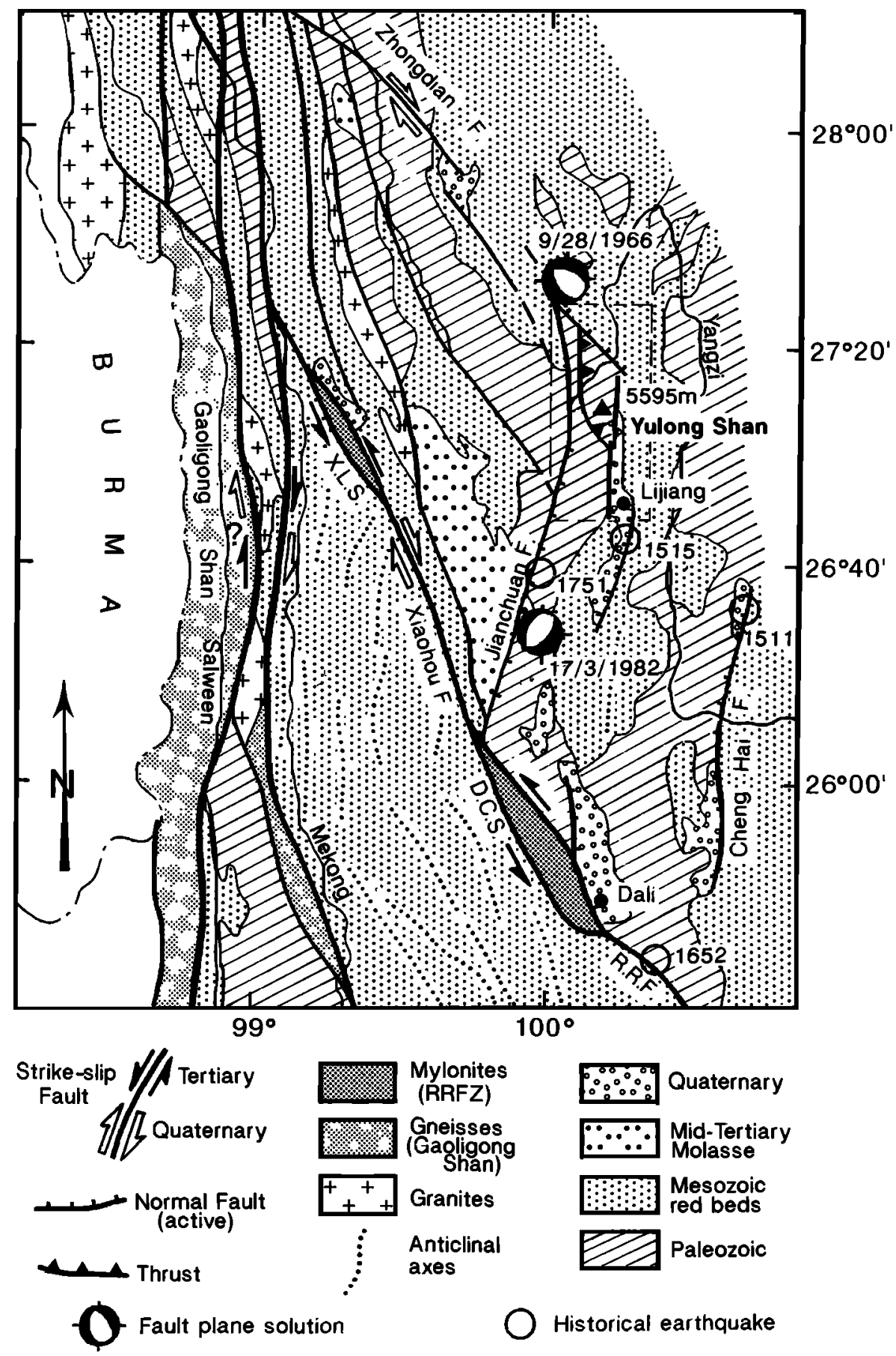

Figure 1b. Simplified structural sketch map of northern Yunnan after Leloup et al. [1995], showing location of Yulong Shan. Abbreviations are D.C.S., Dian Cang Shan; X.L.S., Xue Long Shan; R.R.F., Red River Fault zone. Dashed box refers to Figure 3.

3) and the flat floor surface of the Lijiang basin (c on Figure 3). West of Daju, the Daju Fault limits the northeastern flank of Haba Xue Shan and seems to continue SE of Daju (d on Figure 3 ). This fault strikes $N 130^{\circ} \mathrm{E}$, roughly parallel to the right-lateral Zhongdian and Xiaohou strike-slip faults (Figure lb). The village of Daju is located on top of thick ( $\geq 200 \mathrm{~m}$ ) flat Quaternary terraces that fill a small intermontane basin
(Figures 4, 5, and 6a). We infer this accumulation of clastic sediments on the hanging wall of the Daju fault to result from normal downthrow on that fault. The Jinsha River, which flows here at $\approx 1580 \mathrm{~m}$ above sea level (asl), has incised the terraces by about $150 \mathrm{~m}$. Upstream, on the footwall of the Daju Fault, much thinner terraces rest unconformably on the steeply dipping marbles of the northeastern flank of the Yulong Shan 


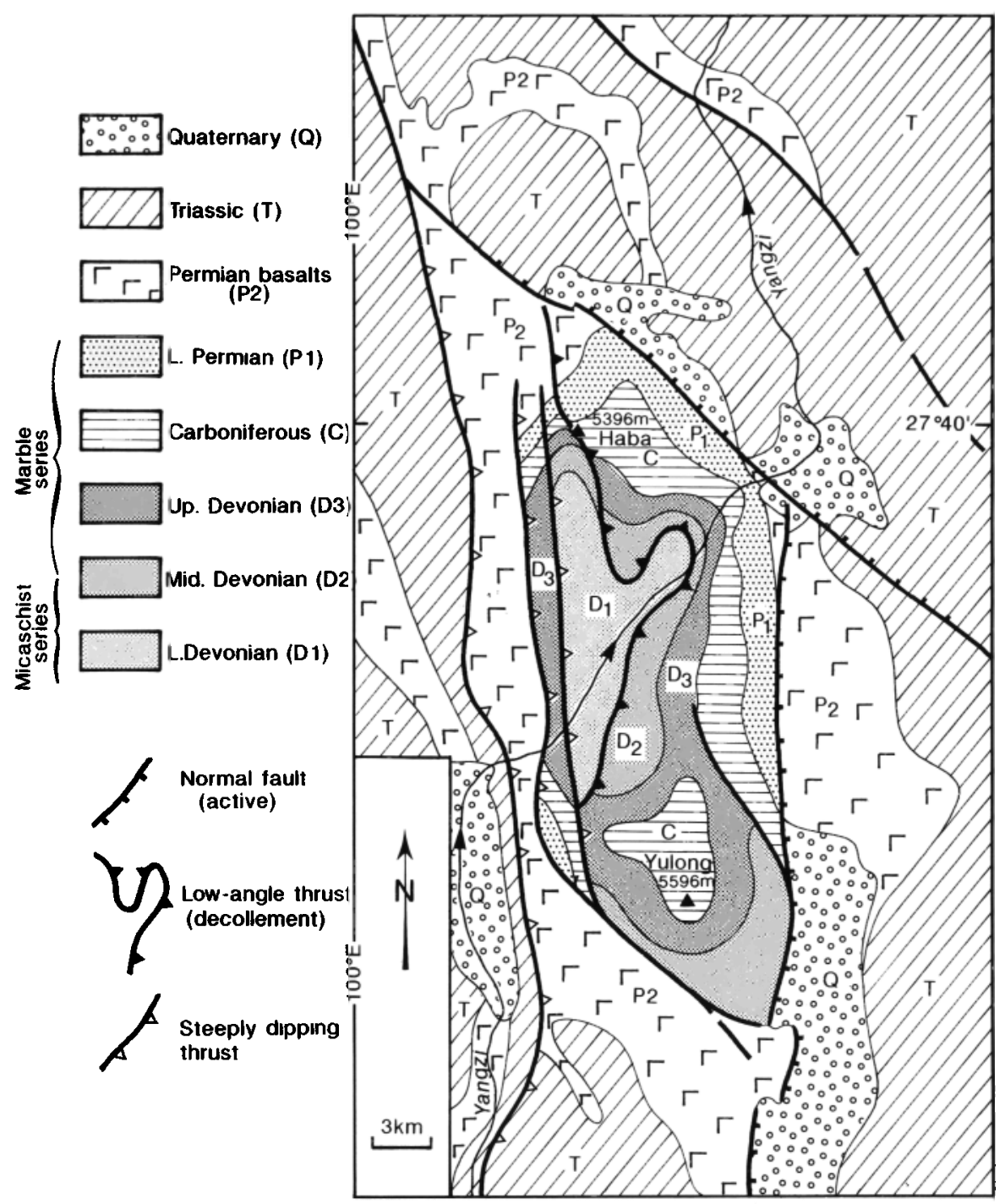

Figure 2. Simplified geological sketch map of Yulong Shan, modified after 1:500,000 geologic map of Yunnan [ Geological Bureau of Yunnan Province, 1979].

range, about $50 \mathrm{~m}$ above the Daju terrace surface (Figures $6 \mathrm{a}$ and $6 \mathrm{~b})$.

On most extant maps [Geological Bureau of Yunnan Province, 1979; Bureau of Geology and Mineral Resources of Yunnan, 1983] the Yulong Shan corresponds to a broad N-S antiform exposing the Paleozoic series of the Yangzi platform (Figure 2). The main topographic crest of the range outlines the top of this antiform (Figures 3 and 4). On the 1:106 geological map of Yunnan [Bureau of Geology and Mineral Resources of Yunnan, 1983], the Yulong Shan is mapped as a simple west facing anticline folding Lower Devonian to Permian beds, while its structure appears more complex on the 1:500 000 geological map [Geological Bureau of Yunnan Province, 1979] (Figure 2). In and along the western flank of the antiform the latter map shows steep, apparently reverse, N-S faults (Figure 2) cutting a shallower dipping fault in the core of the antiform. In part, the latter fault roughly follows the boundary between lower (D1) and middle (D2) Devonian, suggesting that it might be a décollement or detachment refolded by the antiform (Figure 2). Between Lunan and Daju

Figure 3. Map of structural data obtained in Yulong Shan massif. Circled letters a to $\mathrm{d}$ refer to sites cited in text. View points for photographs of Figures $6 a$ and $6 b$ are also located on map. Circled letters $U$ and $D$ point to upstream and downstream parts of Hu Tiao gorge and correspond to diagrams of Figures $10 \mathrm{a}$ and $10 \mathrm{~b}$, respectively. Cross section A-B corresponds to synthetic section of Figure 5. Fault plane solutions (lower hemisphere) and open circles correspond to epicenters of instrumental and major historical earthquakes, respectively. Topography is from 1:100,000 Chinese topographic maps (contour spacing is $200 \mathrm{~m}$ ). 


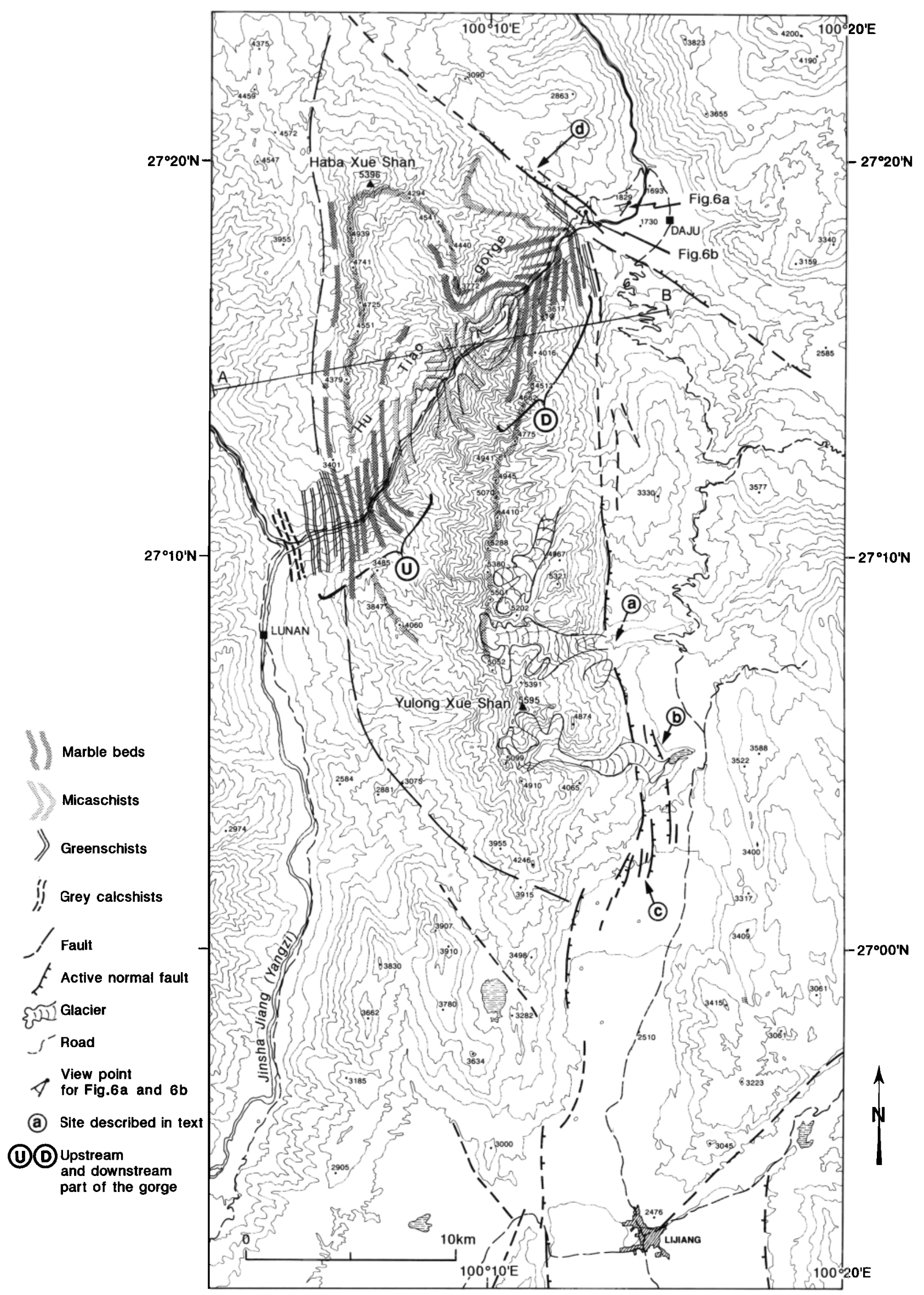

Figure 3. 

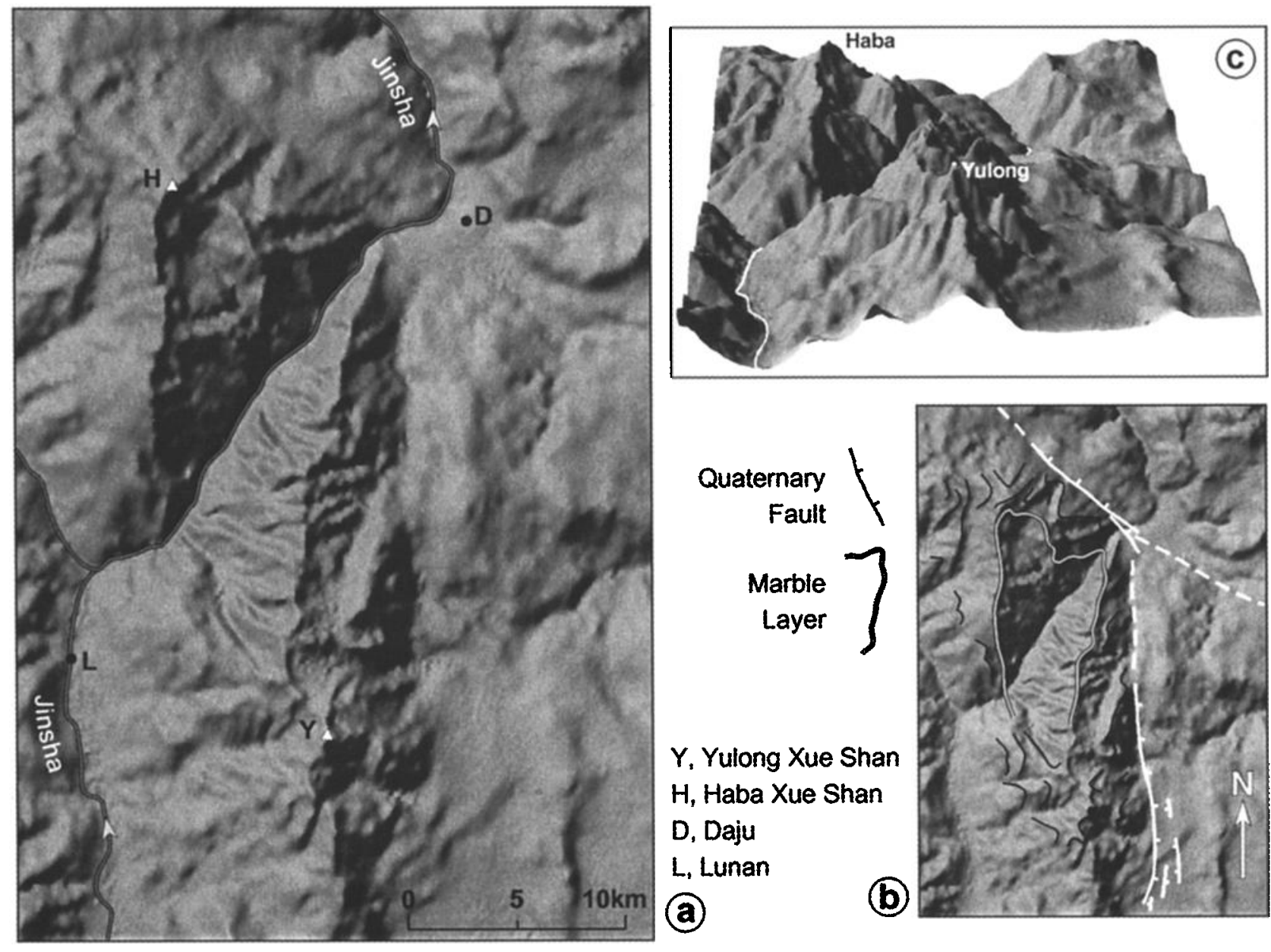

Figure 4. Digital elevation model (DEM) of Yulong Shan (gridded topography extracted from 1:100,000 topographic maps). (a) Shaded vertical view with illumination from NW. Main crests of Yulong and Haba ranges outline shape of antiform (Figures 3 and 5). Quaternary normal faults bound steep eastern flanks of these ranges (Figure 3). (b) Structural sketch showing contours of one marble layer, strong horizons above, and normal faults at base of eastern flank. (c) Three dimensional view of DEM taken from the south and illuminated from NW.

(Figure 3), the Jinsha Jiang has cut across the antiform a $\approx 3500$-m-deep "cluse" (specific term for a river incised wind gap transverse to an anticline), possibly one of the greatest in the world, forming the famous "Tiger-leap" gorge (Hutiao $\mathrm{Xia}$ ), (Figures 4, 6a and 6b). This narrow gorge provides a spectacular, fairly complete, section of the Yulong antiform, accessible along a foot path on the left bank of the Jinsha River (Figures 3 and 5).

\subsection{Hutiao Gorge Section}

2.3.1. Overall structure of the Hutiao gorge section. Entering the gorge from the NE, one first encounters the steep Daju Fault zone, marked by brecciated marbles and slices of red sandstones (possibly of upper Triassic or Jurassic age). SW of this fault, greenschists (with quartz, white micas, chlorite, biotite, actinolite, epidote), which we infer to correspond to metamorphosed Permian basalts, lie conformably on top of thick, $30^{\circ}-50^{\circ} \mathrm{E}$ dipping marbles (upper Devonian to
Permian ?) (Figures 3 and 5). Particularly strongly deformed light grey marbles and calcschists, containing horizons of greenish to light brown schists and boudins of amphibolites or basalts, form spectacular slabs at the entrance of the gorge (Figures 6a and 6b). The marbles grade downward into black schists and slates with more marbles and dolomitic horizons with some amphibolite boudins (Figure $6 \mathrm{c}$ ), in turn overlying less deformed white yellow marbles bearing white and pink micas (muscovite, phlogopite).

A series of black and grey schists and micaschists with quartzite and greywacke layers, in which cross bedding is locally preserved (normal polarity), crops out in the deepest part (core) of the antiform (Figures 3 and 5). Such schists probably derive from finely laminated sandstones and volcaniclastic rocks (lower Devonian?). The micaschists bear biotite (often forming elongated centimetric spots on the foliation planes), muscovite, chlorite, and ribbons of small $(<100 \mu \mathrm{m})$, nearly isotropic grains of quartz, $\mathrm{K}$ feldspar, and plagioclase. In some samples, chlorite and muscovite underline a crenu- 


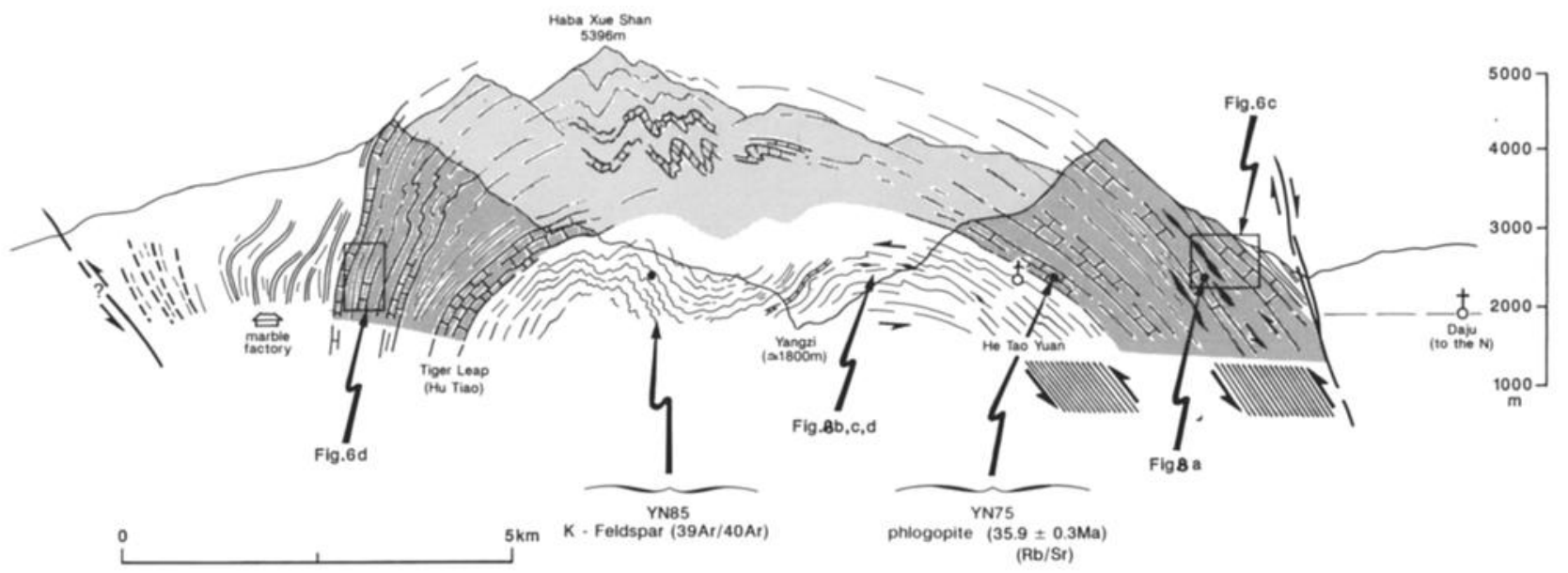

Fमf Marble and calcschists $_{\text {Amphibolite boudins }}$

Figure 5. Synthetic section of Yulong Shan massif through Hu Tiao gorge (section trace located on Figure 3). Structural observations along Hu Tiao gorge are projected parallel to antiform axis.

lation cleavage parallel to axial planes of minor decimetric folds affecting the foliation planes (Figure 5). The micaschists also contain porphyroclasts $(\approx 500 \mu \mathrm{m})$ of carbonate minerals, which we infer to be siderite $\left(\mathrm{CO}_{3} \mathrm{Fe}\right)$ from their high refringence. Association of biotite, chlorite and muscovite indicates greenschist metamorphic grade. In spite of the availability of $\mathrm{Ca}, \mathrm{Al}$, and $\mathrm{Fe}$, no grossular or andradite garnets formed in the micaschists, suggesting that temperature never exceeded $450^{\circ} \mathrm{C}$ in the deepest part of the Yulong Shan antiform.

Toward the west, in the western limb of the antiform, the marbles are found again, with almost the same lithological units as in the eastern limb (Figures 3 and 5), but with less intense deformation. At the famous Tiger-leap locality (rapids in the narrowest part of the gorge), vertical to overturned marble beds (Figures 5 and $6 \mathrm{~d}$ ) form a sharp N-S crest (Figures 3, 4, 5, and 6d). West of these marbles, vertical to overturned greenschists (metabasalts ?) overlie east dipping grey calcschists of probable Triassic age (Figure 5).

Overall, along the Tiger-leap gorge section, the Yulong Shan antiform is thus best interpreted as a simple west verging anticline as suggested by inspection of the geological maps. Minor complications, in the form of smaller-scale folds, are mostly found near the hinge of the anticline (Figure 5). Along section, however, we found inconclusive evidence for the reverse faults cutting the western flank of the antiform (Figure 2). Such faults, if they exist, must be steep and almost parallel to the nearly vertical bedding.

2.3.2 Microstructures: Characters of ductile strain. A well-developed, bedding-parallel foliation affects most of the marbles and schists along section (Figure 7). Together with the stretching lineation, which is very spectacular at places (Figure $8 \mathrm{a}$ ), the foliation is thus folded by the antiform.
Ductile deformation has been particularly strong in the marbles of the eastern flank and in the micaschists that underly the marbles (Figures 5 and 9). There, bedding-parallel shear has produced intense compositional banding of the rocks with pervasive boudinage of stiffer layers (amphibolites, quartz veins) and, locally, sheath folds (Figure $8 \mathrm{~b}$ ).

Bedding and foliation planes strike $\mathrm{N}-\mathrm{S} \pm 30^{\circ}$. A great circle best fitting the distribution of bedding-foliation poles defines an antiformal axis very close to $\mathrm{N}-\mathrm{S}\left(\mathrm{N} 175^{\circ} \mathrm{E}-\alpha 95: 4^{\circ}\right)$ (Figure 7). Stretching lineation pitches in the foliation planes are toward the north $\left(30\right.$ to $\left.75^{\circ} \mathrm{N}\right)$ and toward the south (35 to $60^{\circ} \mathrm{S}$ ) in the eastern and western limb of the antiform, respectively (Figures $10 \mathrm{a} \& 10 \mathrm{~b}$ ). Unfolding about the antiform axis restores the lineations in the two limbs to the same $N 40^{\circ} \mathrm{E}$ average direction while bringing the foliation-beding poles to near vertical (Figures $10 \mathrm{c} \& 10 \mathrm{~d}$ ). Lineations measured on gently dipping foliations in micaschists of the core strike $\mathrm{N} 10^{\circ} \mathrm{E} \pm 10^{\circ}$ with pitches generally close to $0^{\circ}$ (Figure 7 ), suggesting that bedding-parallel shear slightly closer to $\mathrm{N}-\mathrm{S}$ might have occurred at deeper levels in the Paleozoic series below the marble beds.

Shear sense indicators in sections parallel to the stretching lineation, though relatively scarce, are consistent with top toward the SSW transport, on either flank and in the core of the antiform (Figures $8 \mathrm{c}$ and $8 \mathrm{~d}$ ). Such criteria include asymmetric boudinage of stiffer layers [Gaudemer and Tapponnier, 1987; Hanmer and Passchier, 1991], asymmetric pressure shadow crystallisations [Etchecopar and Malavieille, 1987] adjacent to pyrite crystals within marbles of the eastern flank, SSW verging drag folds of metric to decametric scale, and, at the microscopic scale, $\mathrm{C}$ or $\mathrm{C}^{\prime} / \mathrm{S}$ microstructures [Berthé et al., 1979a, b]. 

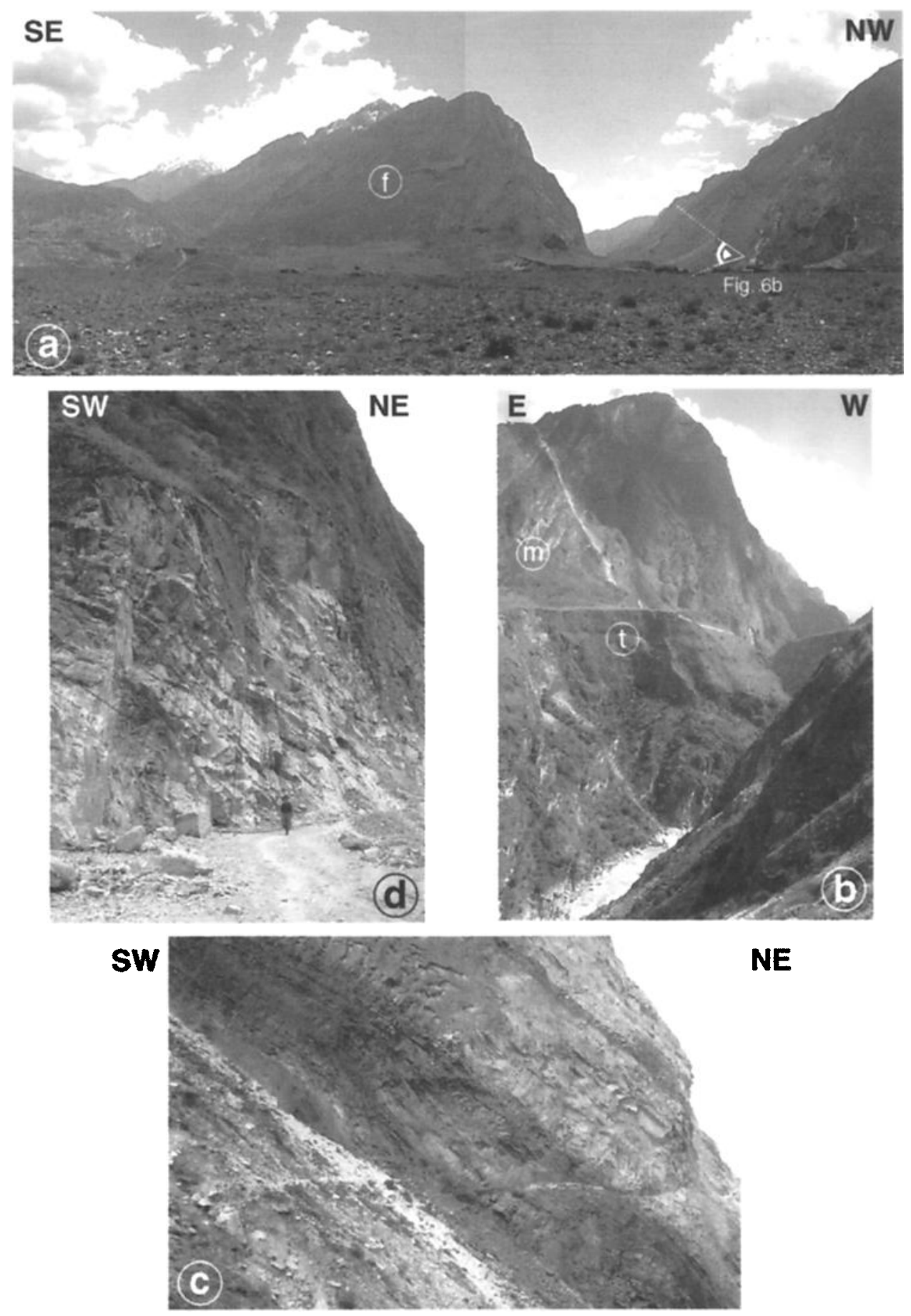

Figure 6. (a) Panoramic view of northeastern flank of Yulong Shan and Hutiao gorge. Flat surface in foreground is top of Daju basin Quaternary fill. Circled letter $f$ shows triangular facet in part related to Quaternary normal faulting. View point of Figure $6 \mathrm{~b}$ is shown. (b) View of cliffs above downstream part of Hutiao gorge (view point located on Figures 3 and $6 \mathrm{a}$ ). Circled letters $\mathrm{m}$ and $\mathrm{t}$ point to east dipping marble beds and Quaternary terrace on footwall of Daju fault, respectively. (c) Series of strongly deformed marbles and dark grey calcschists of eastern flank of Yulong antiform (view located on Figure 5). (d) Nearly vertical marble series of the western flank of the antiform (view located on Figure 5). 


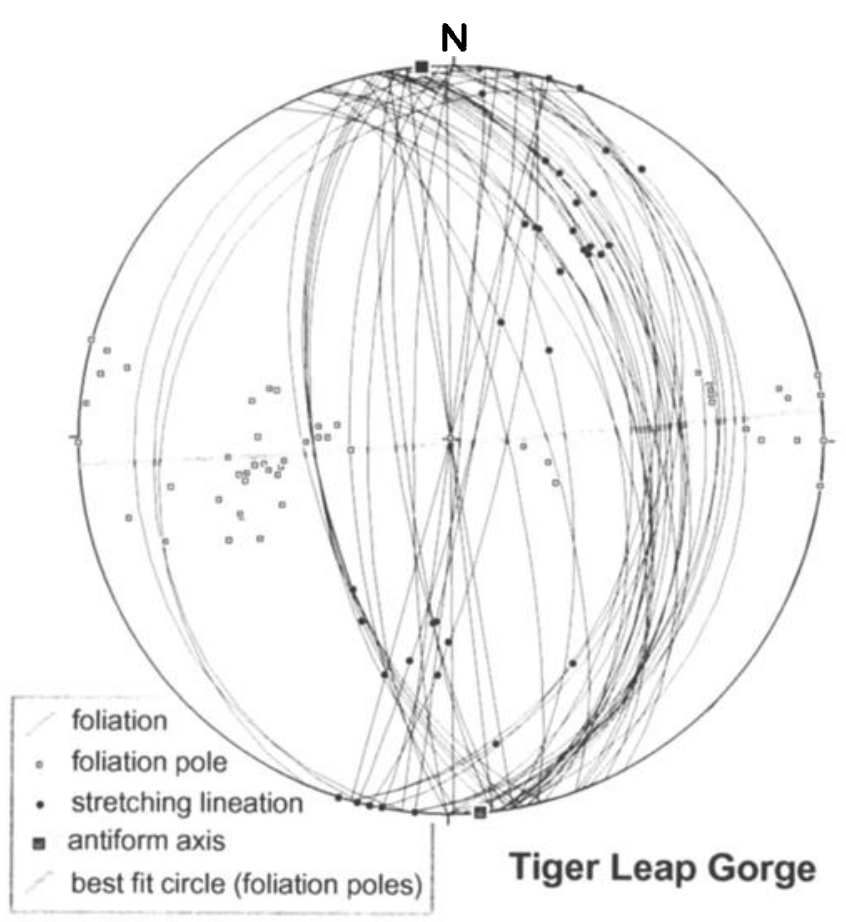

Figure 7. Structural data from Hu Tiao (Tiger-leap) gorge section (Schmid diagrams, lower hemisphere).

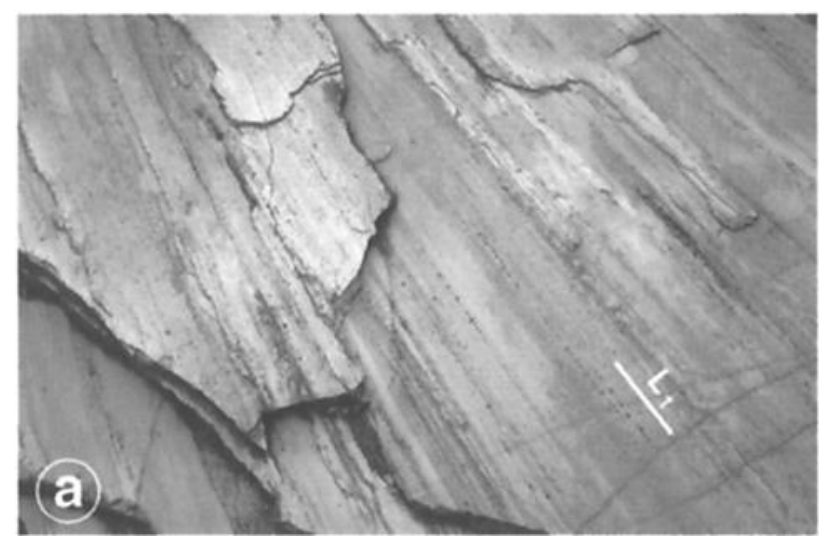

The bulk of our microstructural observations thus suggests that the Yulong-Haba range exposes two bedding-parallel shear zones, with intense deformation localized in two distinct kilometer-thick layers, one in the upper part of the marble series and the other in the underlying micaschists (Figures 5 and 9). Both zones have been subsequently refolded by the antiformal growth of the range. As shear occurred mostly parallel to bedding (Figures 5 and 9) ithout disturbing much the stratigraphic succession (Figures 2 and 3), such zones essentially correspond to a décollement. Transport on this ductile décollement occurred parallel to the direction of stretching lineations prior to refolding, thus toward the SW to SSW in the present-day geographical coordinates. The strong banding and elongation of the rocks, and the occurrence of sheath folds, suggest that finite shear strain has been large in the most deformed layers ( $\gamma \geq 10$ [e.g., Lacassin and Mattauer, 1985]). An average $\gamma$ of 10 within the 2-km-thick layers (Figures 5 and 9) would imply a displacement of $20 \mathrm{~km}$, yielding a rough estimate of the amount of transport on the Yulong Shan décollement. The fact that the marbles of the western limb of the antiform seem less deformed than those from the eastern limb may be taken to suggest that a splay thrust ramp absorbed part of the motion upsection in the sedi mentary sequence between the two limbs. Such ramping upsection is compatible with the geological contours outlined on Figure 2 [Geological Bureau of Yunnan Province, 1979], which shows the fault separating D1 and D2 to cut the strati-

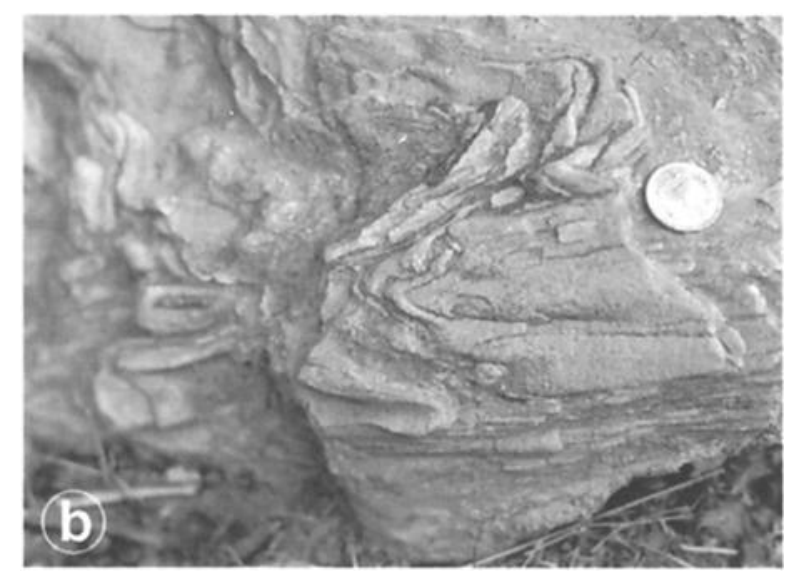

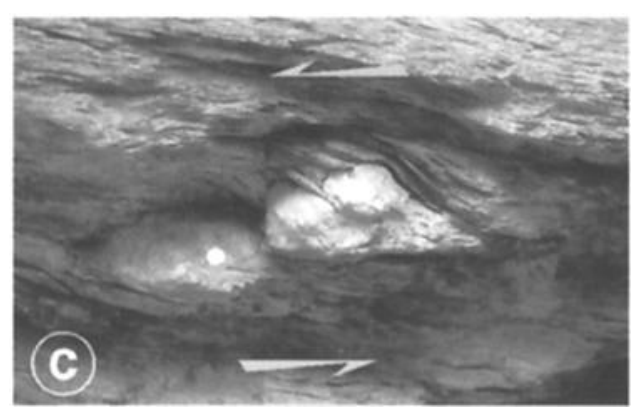
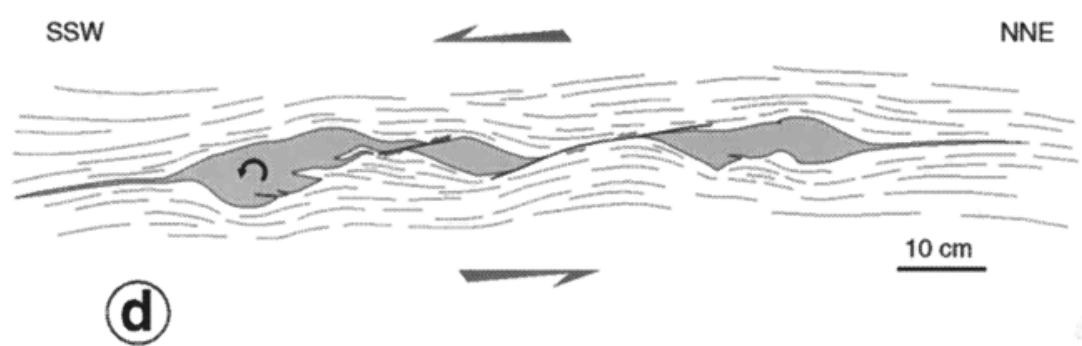

Figure 8. (a) Stretching lineation $\left(\mathrm{L}_{1}\right)$ in east dipping marbles of western flank of antiform (site located on Figure 5). (b) Sheath folds in quartzites of Yulong Shan antiform core (site located on Figure 5). (c-d) Asymmetric deformation around quartz boudins and asymmetric boudinage implying SSW directed shear (site located on Figure 5). 


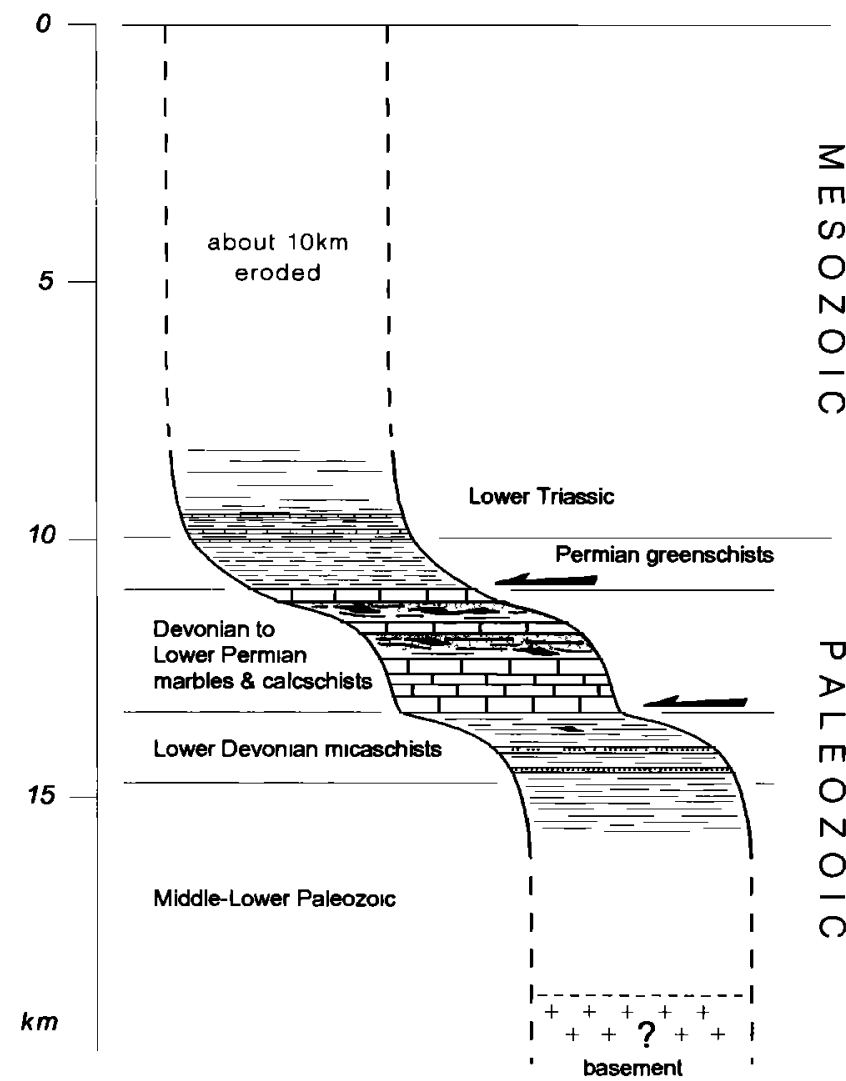

Figure 9. Sketch of Mesozoic Paleozoic stratigraphy showing location of Yulong Shan bedding-parallel shear zones. From greenschist grade of metamorphism, shear is inferred to have occurred at depth of the order of 12 to $15 \mathrm{~km}$. A $\geq 10 \mathrm{~km}$ thick pile of Mesozoic rocks, probably tectonized and thick ened, stood above sheared middle/upper Paleozoic rocks.

graphic succession in the mountains north and south of $\mathrm{Hu}$ Tiao gorge. The 100-meter-scale parasitic folds, exposed at $\approx 4000 \mathrm{~m}$ asl in the marble cliffs on either side of the gorge (Figure 5a), could also result from upward ramping rather than disharmonic strain near the antiform axis, but our fieldwork is insufficient to prove or disprove either inference. The steep reverse faults along the western flank of Yulong Shan (Figure 2), if shown to exist, would correspond to later thrusts, probably coeval with antiformal folding of the décollement.

\section{Rb-Sr Dating of Tectonics and Metamorphism in the Tiger-Leap Gorge}

\subsection{Sample Description and Dating Concept}

To determine the age of greenschist metamorphism and deformation in the rocks of the Yulong Shan décollement, a phlogopite-rich marble ( $\mathrm{YN}-75$ ) was collected at the base of the marble series in the gorge, near He Tao Yuan (Figure 5). This rock is composed of alternating layers of white calcite and white, yellowish to salmon-pink micas that occur in different proportions and varying thickness. The mica flakes are oriented parallel to this lithologic banding, having grown within the foliation planes. Because of this strictly bimodal mineralogical composition between calcite matrix and mica, a conventional approach for $\mathrm{Rb}-\mathrm{Sr}$ dating was not possible, and an attempt was made to determine the age by a micainternal isochron using different mica-size fractions. This technique has been used for U-Pb dating on accessory minerals, the assumption here being that small and large micas might have formed with different $\mathrm{Rb} / \mathrm{Sr}$ ratios reflecting early or late stages of growth from domains with time-dependent variations of the $\mathrm{Rb} / \mathrm{Sr}$ ratio. Such changes in parent-daughter element ratios were assumed to be caused by fluid diffusion in association with metamorphism and deformation and by metamorphic reactions producing the banded marble. Potentially, such variation ought to be relatively easy to detect in mica, because this mineral is very rich in $\mathrm{Rb}$ and poor in $\mathrm{Sr}$ compared to the marble matrix and even very minor $\mathrm{Sr}$ exchange drastically modifies the $\mathrm{Rb} / \mathrm{Sr}$ ratio. As listed in Table 1, such exchange is in fact demonstrated by the $\mathrm{Rb}$ and Sr concentrations measured in five different mica fractions, the whole rock, and the matrix. The values document exceptional $\mathrm{Rb} / \mathrm{Sr}$ fractionation between the rock and its micas, confirming that the ratio must be, as suspected, grainsize dependent.

\subsection{Rb-Sr Dating Results}

All phases analyzed (Table 1) were selected from a sample of marble (YN-75, Figure 5), weighting about $2 \mathrm{~kg}$ and showing well-defined calcite-phlogopite layering. The mica layers consist almost exclusively of phlogopite flakes oriented parallel to that layering, i.e., to the foliation plane of the rock. The whole rock analysis (submicron powder) was obtained from a representative split including marble matrix and micas, whereas the matrix was selected from a homogeneous calcite layer in between two mica layers. The different phlogopite size fractions were separated from the total mass of phlogopite available in the cube. Figure 11 shows the isochron diagram for the seven different analyses performed, defining a linear regression line that corresponds to an age of $35.9 \pm 0.3(2 \sigma)$ Ma. Although the data show a slight scatter along this isochron $\left(\sigma^{2}\right.$ red $=5.8$; mean square weighted deviate $(M S W D)=23$ ), the regression is of sufficient quality to interpret the $35.9 \mathrm{Ma}$ age as that of metamorphism, i.e., of mica growth in equilibrium with formation of the marble. The slight scatter can be ascribed either to very local disequilibrium conditions (small variation in initial $\mathrm{Sr}$ isotopic compositions at the centimeter scale) or to later weak $\mathrm{Rb}-\mathrm{Sr}$ exchange between matrix and micas. Such small postcrystallization changes in $\mathrm{Rb} / \mathrm{Sr}$ would be strongly enhanced by the extreme contrast, as mentioned above, of $\mathrm{Rb}$ and $\mathrm{Sr}$ concentrations between matrix and micas (Table 1). The lowest $\mathrm{Rb}$ and highest $\mathrm{Sr}$ abundance is measured in the calcite matrix (5 and $406 \mathrm{ppm}$, respectively), whereas the largest phlogopites show an exactly inverse pattern (785 and $5 \mathrm{ppm}$, respectively). It is this exceptional contrast that allows us to determine a precise age by a mineral-internal $\mathrm{Rb}-\mathrm{Sr}$ isochron, as demonstrated here for the first time. Up to now, mineral isochrons have mostly been derived from analysis of different minerals in the same rock, not size fractions of the same mineral.

Since the average local temperatures during the metamorphic event are unlikely to have reached the closure temperature of $\mathrm{Rb}-\mathrm{Sr}$ in white mica $\left(\approx 500^{\circ} \mathrm{C}\right)$, the $35.9 \mathrm{Ma}$ age can unambiguously be interpreted as the age of phlogopite crystal- 

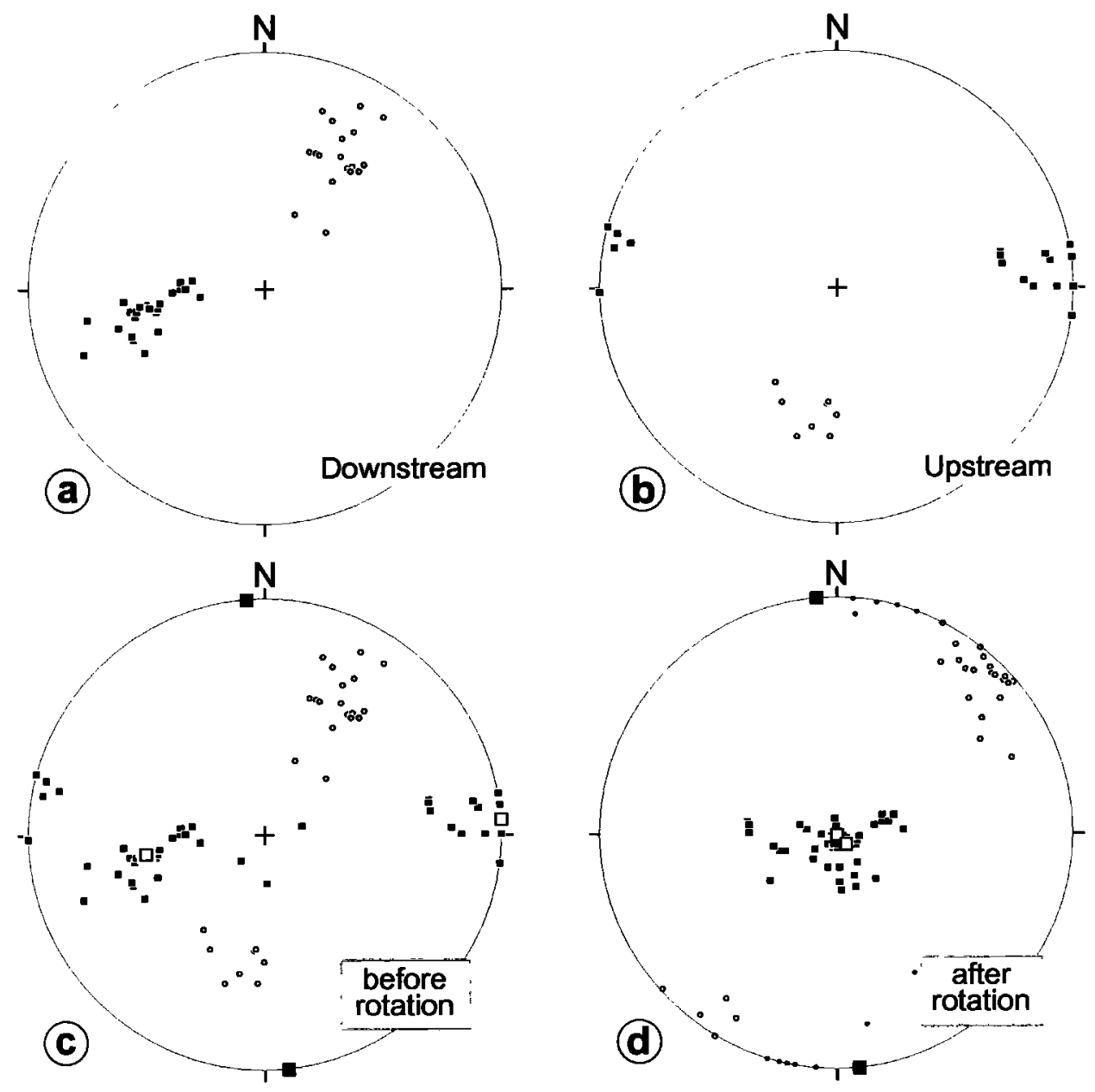

- foliation pole

- lineation from $E$ and $W$ flank

- lineation from Yulong core

口 mean foliation poles (up \& down stream)

- rotation axis

Figure 10. Restoration of shear direction on ductile décollement before antiformal folding. (a) Data corresponding to eastern flank of antiform (downstream part of the gorge, circled D on Figure 3). (b) Data corresponding to western flank of antiform (upstream part of the gorge, $U$ on Figure 3). (c) Data from both flanks before rotation. (d) After rotation of $45^{\circ}$ (downstream data) and $90^{\circ}$ (upstream data), about antiform axis (shaded square). Lineations are restored to mean $\mathrm{N} 40^{\circ} \mathrm{E}$ direction. Unrotated lineations from Yulong core (gently dipping foliations) strike $\approx \mathrm{N} 10^{\circ} \mathrm{E}$, thus closer to $\mathrm{N}-\mathrm{S}$ (Figure 8). Transport was to SW to SSW in present-day coordinates.

lization and growth during the greenschist facies metamorphism that accompanied SW to SSW directed shear on the ductile décollement (Figure 12a).

\section{Insight on the Cooling History From ${ }^{39} \mathrm{Ar} /{ }^{40} \mathrm{Ar}$ Feldspar Dating}

In order to put additional constraints on the metamorphic and cooling history of the Yulong Shan, we attempted to date K-feldspars extracted from one sample of quartzo-feldspathic micaschists, using the ${ }^{39} \mathrm{Ar} /{ }^{40} \mathrm{Ar}$ technique. This sample (YU-
85) comes from a zone affected by minor refolding of the bedding/foliation planes in the core of the antiform (Figure 5). It is made of alternating light and dark grey layers bearing mainly quartz-feldspar and biotite, respectively. Using heavy liquids, $14.43 \mathrm{mg}$ of $\mathrm{K}$-feldspar of fraction size between 250 and $150 \mu \mathrm{m}$ were separated from the whole crushed sample. Under binoculars, these feldspars appeared of poor quality with irregular and composite grains. They were irradiated in the Ford reactor, University of Michigan, at position L67 for 45 hours in the same tube as Fish Canyon sanidines (FC-3), pure $\mathrm{K}_{2} \mathrm{SO}_{4}$ crystals, and $\mathrm{CaF}_{2}$ salts. Argon isotopes liberated 
Table 1. Rb-Sr Analytical Results for Different Size Fractions of Phlogopite From Marble Sample YN-75

\begin{tabular}{|c|c|c|c|c|}
\hline \multirow[t]{2}{*}{ Sample } & \multicolumn{2}{|c|}{ Concentration, ppm } & \multirow[t]{2}{*}{${ }^{87} \mathrm{Rb} /{ }^{86} \mathrm{Sr}$} & \multirow[t]{2}{*}{$\left({ }^{87} \mathrm{Sr} /{ }^{86} \mathrm{Sr}\right)_{\mathrm{nom}}$} \\
\hline & $\mathbf{R b}$ & $\mathbf{S r}$ & & \\
\hline Marble matrix & 5.05 & 406 & 0.299 & $0.71215 \pm 3$ \\
\hline Whole rock & 19.4 & 80.7 & 0.692 & $0.71291 \pm 4$ \\
\hline Phlogopite I $<315 \mu \mathrm{m}$ & 611 & 27.0 & 64.9 & $0.74246 \pm 2$ \\
\hline Phlogopite II 315-800 $\mu \mathrm{m}$ & 709 & 8.82 & 231 & $0.82732 \pm 4$ \\
\hline Phlogopite III 315-800 $\mu \mathrm{m}$ & 678 & 6.88 & 283 & $0.85742 \pm 4$ \\
\hline Phlogopite IV > $800 \mu \mathrm{m}$ & 717 & 5.06 & 406 & $0.93171 \pm 5$ \\
\hline Phlogopite $\mathrm{V}>800 \mu \mathrm{m}$ & 785 & 5.02 & 449 & $0.94600 \pm 3$ \\
\hline
\end{tabular}

The $\left({ }^{87} \mathrm{Sr} /{ }^{86} \mathrm{Sr}\right)$ norm is normalized to ${ }^{86} \mathrm{Sr} /{ }^{88} \mathrm{Sr}=0.1194$. Analytical uncertainties are $\pm 2 \%$ for ${ }^{87} \mathrm{Rb} /{ }^{86} \mathrm{Sr}$, and for $\left({ }^{87} \mathrm{Sr} /{ }^{86} \mathrm{Sr}\right)_{\text {norm }}$, they are given in table 1 , on the last digit of the values measured. Replicate analyses of National Bureau of Standards (NBS) $987 \mathrm{Sr}$ standard yielded a value of $0.71025 \pm 3$ for $\left({ }^{87} \mathrm{Sr} /{ }^{86} \mathrm{Sr}\right)$ norm during the period of analytical work. The ${ }^{87} \mathrm{Rb}$ decay constant used is $1.42 \times 10^{-11} /$ year [Steiger and Jäger, 1977]. $\mathrm{Rb} / \mathrm{Sr}$ were determined by the isotope dilution method using a mixed ${ }^{84} \mathrm{Sr} /{ }^{85} \mathrm{Rb}$ spike added to aliquots of the solution, whereas whole rock and matrix analyses were spiked totally prior to dissolution. Prior to dissolution, all micas were washed at about $40^{\circ} \mathrm{C}$ in $1 \mathrm{~N} \mathrm{HCl}$ for about $20 \mathrm{~min}$.

by these feldspars under progressive step heating were mea sured in the mass spectrometer of the University of Clermont Ferrand. The $J$ factor calculated assuming an age of $27.8 \mathrm{Ma}$ for the fish Canyon sanidines [Miller et al., 1985] is 0.0074 . Analysis of the $\mathrm{K}_{2} \mathrm{SO}_{4}$ crystals and $\mathrm{CaF}_{2}$ salts yields $\left({ }^{39} \mathrm{Ar} /{ }^{40} \mathrm{Ar}\right) \mathrm{K},\left({ }^{39} \mathrm{Ar} /{ }^{37} \mathrm{Ar}\right) \mathrm{Ca}$, and $\left({ }^{36} \mathrm{Ar} /{ }^{37} \mathrm{Ar}\right) \mathrm{Ca}$ correction factors of $0.021,0.0007$, and 0.00025 , respectively. Results are given in Table 2.

The resulting age spectrum (Figure 13a) shows decreasing ages in the first $20 \%$ of ${ }^{39} \mathrm{Ar}$ release. The steps between $20 \%$

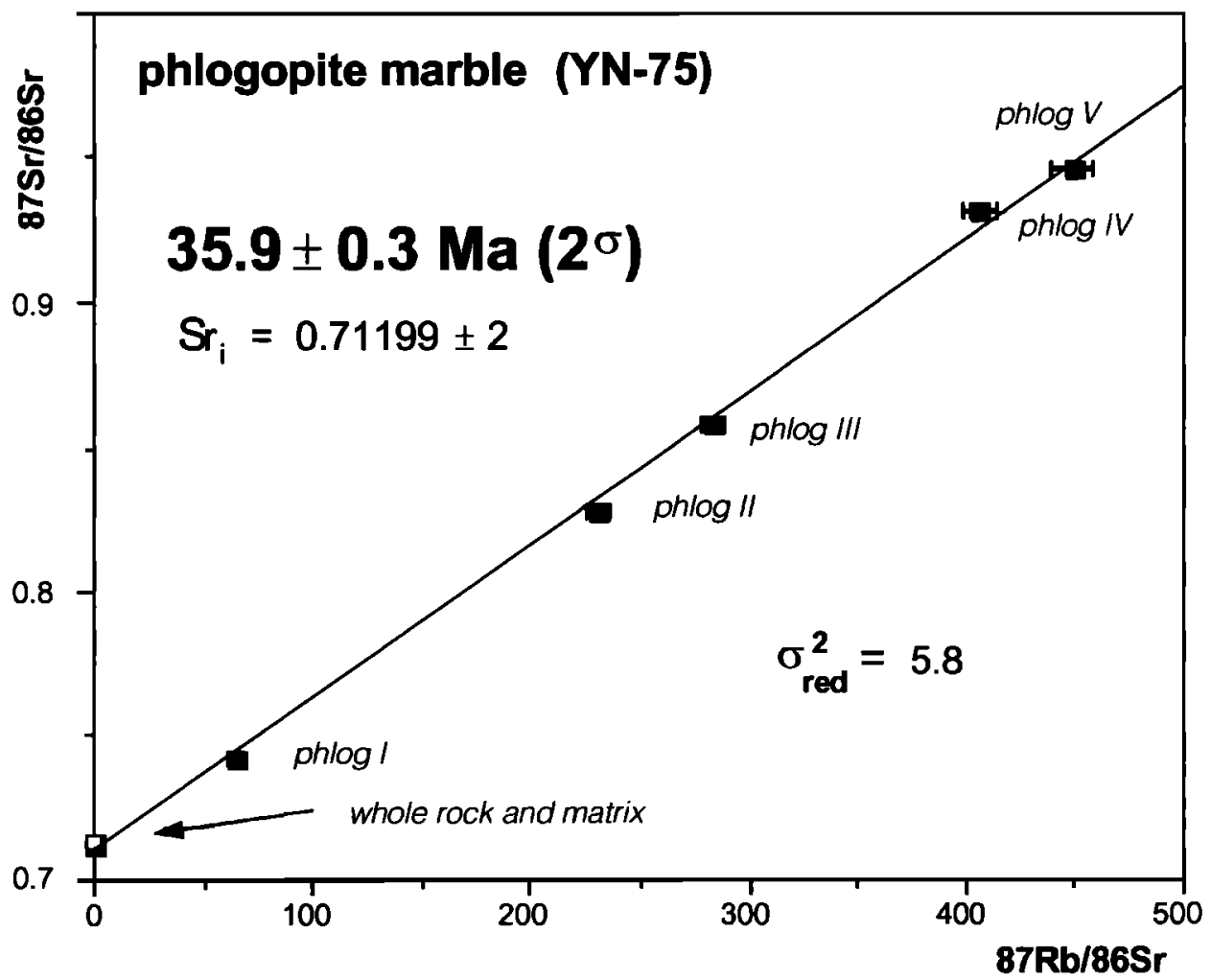

Figure 11. Mineral-internal Rb-Sr isochron resulting from analysis of different size fractions of phlogopites, matrix, and whole rock (marble sample YN-75). Phlogopite crystallization within foliation planes occurred at $35.9 \pm 0.3 \mathrm{Ma}\left(2 \sigma\right.$ error). Initial ${ }^{87} \mathrm{Sr} /{ }^{86} \mathrm{Sr}$ ratio was 0.71199 . 

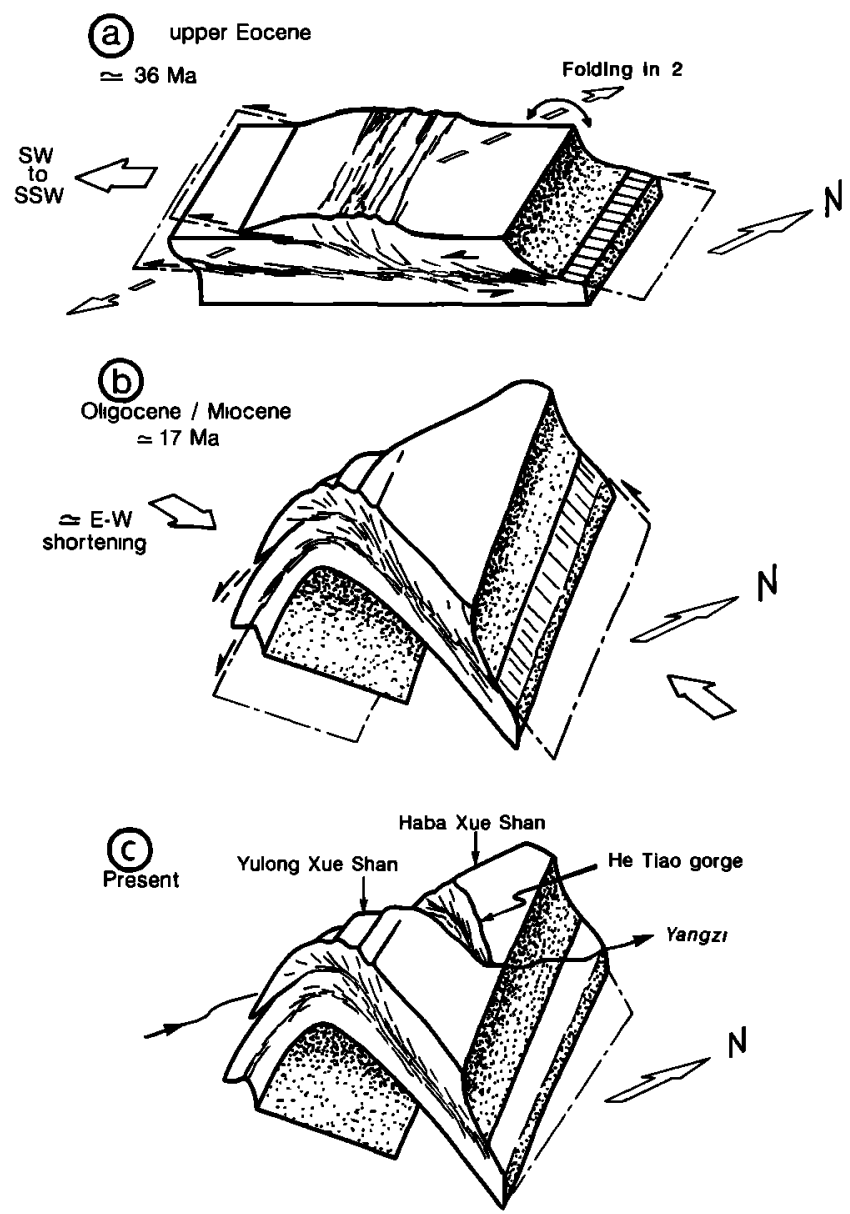

Figure 12. Sketch showing inferred evolution of Yulong Shan Range (see discussion in text). (a) Eocene $(\approx 36 \mathrm{Ma}$ ) transport toward SSW on bedding-parallel ductile décollement. (b) Miocene $(\approx 17 \mathrm{Ma}$ ) antiformal folding of décollement with fold axis oblique to former shear direction. Main uplift and erosion of the range, together with incision by Jinsha Jiang and formation of $\mathrm{Hu}$ Tiao "cluse", are inferred to have occurred during folding, resulting in (c) present geometry.

and $68 \%$ of argon release define a rough plateau, from which an age of $17 \pm 3.5 \mathrm{Ma}(2 \sigma)$ may be calculated. The highest temperature steps (last $20 \%$ of Argon release) are grossly aligned on an even rougher plateau between 48 and $51 \mathrm{Ma}$. On the corresponding Arrhenius diagram (Figure 13b), the lower temperature steps define a curve with a concave shape and wide separations between successive isothermal heatings. In contrast with what is observed with most K-feldspars, whose progressive argon release may be modeled assuming a discrete distribution of domain sizes for argon [Harrison et al., 1991; Lovera et al., 1991], it was impossible here to calculate a model fitting the Arrhenius diagram. Thus we could not retrieve any detailed cooling history from YN85 results. Note that metamorphism reached greenschist facies conditions only; hence temperatures too low to permit crystallization of new K-feldspars. It follows that the analyzed K-feldpars were probably inherited sedimentary grains that suffered Argon loss during Tertiary metamorphism. The usual heating procedure for ${ }^{39} \mathrm{Ar} /{ }^{40} \mathrm{Ar}$ analysis of $\mathrm{K}$-feldspar (Figure $13 \mathrm{c}$ ), which starts at $450^{\circ} \mathrm{C}$, was probably inadequate to precisely unravel the Tertiary thermal history of those feldspars. However, it is possible to interpret the age spectrum of $\mathrm{YN}-85$ as a composite age spectrum. The older, rough plateau around $50 \mathrm{Ma}$ could testify to partial argon loss at the time of peak metamorphism ( $\approx 36 \mathrm{Ma}$ according to the $\mathrm{Rb} / \mathrm{Sr}$ age of $\mathrm{YN}-75$ phlogopites). The better defined, younger plateau most probably corresponds to a phase of rapid cooling sometime between 15 and $20 \mathrm{Myr}$ ago $(17 \pm 3.5 \mathrm{Ma})$.

\section{Summary and Discussion}

Our structural study of the Yulong Shan and the radiometric dating of minerals in its core indicate that motion (in present geographical coordinates) on a flat ductile décollement took place in the late Eocene in the region of Yunnan closest to the Tibetan highlands. That décollement, localized within Devonian and Carboniferous micaschists and marbles (Figure 9), transported $a \approx 10-\mathrm{km}$-thick pile of mostly Mesozoic rocks a few tens of kilometers toward the SSW, relative to lower Paleozoic sediments series and Precambrian basement under neath (Figure 9). Other décollement zones probably existed at shallower or deeper levels in the crust. The moderately deformed lower-middle Paleozoic micaschists and gneisses, with SSW directed lineations and shear senses, found along the Judian-Weixi section about $70 \mathrm{~km}$ east of the Yulong Shan [Leloup et al., 1995], probably correspond to such deeper décollement zones.

It seems likely that kilometer-thick zones of strongly sheared rocks, like those found in the Yulong Shan (Figure 9), are of regional extent and significance. We thus interpret the Yulong Shan décollement, and the ramp thrusts splaying upsection from it (Figure 12)., to result from collisional shortening of the sedimentary cover of the Yangzi platform, due to the penetration of India into Asia. This décollement and possibly deeper ones probably linked midcrustal strain with folding and thrusting of the overlying sediments, thus acting as basal flats underneath a detached fold and thrust belt [Boyer and Elliott, 1982]. It probably rooted on a deep crustal ramp located northward near the border between Sichuan and Tibet. The metamorphism coeval with such thrust transport (35.9 $\pm 0.3 \mathrm{Ma}$ ) is only slightly older than the earliest anatectic melts $(35.0 \pm 0.1 \mathrm{Ma})$ dated along the Ailao Shan-Red River shear zone to the south [Schärer et al., 1994]. Thus transport on the Yulong Shan décollement and related regional overthrusting appears to have been synchronous with the early stages of sinistral motion along this zone.

All models of Asian Tectonics predict large clockwise (CW) rotations in the area located near the eastern Himalayan syntaxis and between the Ailao Shan-Red River and Xianshuihe sinistral fault zones (Figure $1 \mathrm{a}$ and $\mathrm{lb}$ ). $\mathrm{CW}$ rotations of about $50^{\circ}$ have been found in Cretaceous red beds of that area [Funahara et al., 1992, 1993; Huang Kainan and Opdyke, 1993]. It follows that late Eocene transport on the décollement and the related shortening of the overlying series may have been oriented toward the south or south-southeast.

There is growing evidence that other large décollements underlie the sedimentary cover or upper crust of regions surrounding the Eastern Himalayan syntaxis and other parts of 
Table 2. The ${ }^{39} \mathrm{Ar} /{ }^{40} \mathrm{Ar}$ Analytical Results for K-feldspar From Sample YN-85

\begin{tabular}{|c|c|c|c|c|c|c|c|}
\hline $\mathrm{T},{ }^{\circ} \mathrm{C}$ & $\begin{array}{c}\text { Time, } \\
\text { min }\end{array}$ & $\begin{array}{c}{ }^{36} \mathrm{Ar} /{ }^{39} \mathrm{Ar} \\
\times 10^{-3}\end{array}$ & $\begin{array}{c}\%{ }^{79} \mathrm{Ar} \\
\text { Released }\end{array}$ & $-\log \left(\mathrm{D} / \mathrm{1}^{\wedge} 2\right)$ & $\%^{40} \mathrm{Ar}{ }^{*}$ & ${ }^{40} \mathrm{Ar}^{*} /{ }^{39} \mathrm{Ar}_{\mathrm{K}}$ & $\begin{array}{c}\text { Age } \pm \text { s.d. } \\
\mathrm{Ma}\end{array}$ \\
\hline 450 & 10 & 199.53 & 2.04 & 6.26 & 9.65 & 7.37 & $102.9 \pm 19.3$ \\
\hline 450 & 30 & 167.05 & 3.19 & 6.58 & 4.61 & 5.21 & $73.4 \pm 20.2$ \\
\hline 500 & 20 & 16.59 & 4.63 & 6.13 & 6.60 & 3.09 & $44.0 \pm 2.2$ \\
\hline 500 & 30 & 0.0 & 5.65 & 6.34 & 2.49 & 2.13 & $30.3 \pm 0.7$ \\
\hline 550 & 20 & 1.61 & 7.65 & 5.75 & 6.54 & 2.37 & $33.8 \pm 1.0$ \\
\hline 550 & 30 & 0.0 & 9.13 & 5.96 & 2.48 & 1.72 & $24.6 \pm 0.6$ \\
\hline 600 & 20 & 0.89 & 11.50 & 5.49 & 5.37 & 1.87 & $26.7 \pm 0.8$ \\
\hline 600 & 30 & 0.0 & 13.48 & 5.66 & 2.62 & 1.58 & $22.6 \pm 0.5$ \\
\hline 650 & 20 & 1.07 & 16.75 & 5.18 & 4.93 & 1.56 & $22.3 \pm 0.7$ \\
\hline 650 & 30 & 0.0 & 19.59 & 5.34 & 2.01 & 1.05 & $15.1 \pm 0.3$ \\
\hline 700 & 10 & 0.15 & 22.70 & 4.76 & 6.41 & 1.30 & $18.6 \pm 0.5$ \\
\hline 700 & 25 & 0.0 & 26.84 & 4.96 & 2.69 & 0.98 & $14.1 \pm 0.3$ \\
\hline 725 & 25 & 0.0 & 31.32 & 4.86 & 2.63 & 0.96 & $13.8 \pm 0.3$ \\
\hline 770 & 25 & 0.0 & 38.66 & 4.57 & 4.50 & 1.18 & $17.0 \pm 0.4$ \\
\hline 800 & 25 & 0.0 & 48.94 & 4.32 & 6.31 & 1.29 & $18.5 \pm 0.4$ \\
\hline 825 & 25 & 0.0 & 55.80 & 4.42 & 3.85 & 1.21 & $17.4 \pm 0.4$ \\
\hline 850 & 25 & 0.0 & 62.13 & 4.40 & 3.59 & 1.28 & $18.4 \pm 0.4$ \\
\hline 900 & 25 & 0.0 & 67.94 & 4.40 & 3.66 & 1.57 & $22.5 \pm 0.6$ \\
\hline 925 & 25 & 0.0 & 72.70 & 4.45 & 2.92 & 1.59 & $22.8 \pm 0.6$ \\
\hline 950 & 25 & 0.0 & 76.50 & 4.52 & 2.66 & 1.90 & $27.2 \pm 0.7$ \\
\hline 975 & 25 & 0.0 & 78.91 & 4.70 & 2.29 & 2.69 & $38.2 \pm 0.9$ \\
\hline 1000 & 25 & 0.0 & 80.84 & 4.79 & 2.31 & 3.51 & $49.8 \pm 1.3$ \\
\hline 1025 & 25 & 0.0 & 82.98 & 4.73 & 2.25 & 3.58 & $50.7 \pm 1.3$ \\
\hline 1050 & 25 & 0.11 & 85.66 & 3.96 & 2.50 & 3.62 & $51.4 \pm 1.3$ \\
\hline 1050 & 30 & 0.0 & 87.77 & 4.44 & 1.46 & 3.20 & $45.5 \pm 1.2$ \\
\hline 1050 & 40 & 0.0 & 89.72 & 4.53 & 1.46 & 3.47 & $49.2 \pm 1.3$ \\
\hline 1050 & 60 & 2.10 & 91.89 & 4.57 & 1.64 & 3.50 & $49.7 \pm 1.5$ \\
\hline 1050 & 80 & 4.30 & 93.57 & 4.70 & 1.35 & 3.72 & $52.7 \pm 1.9$ \\
\hline 1050 & 120 & 8.22 & 95.30 & 4.75 & 1.61 & 4.33 & $61.2 \pm 2.5$ \\
\hline 1050 & 25 & 12.86 & 95.46 & 5.01 & 0.36 & 3.36 & $47.7 \pm 2.7$ \\
\hline 1075 & 60 & 0.0 & 96.97 & 4.34 & 1.07 & 3.70 & $52.5 \pm 1.2$ \\
\hline 1075 & 120 & 16.59 & 98.39 & 4.44 & 1.16 & 4.29 & $60.7 \pm 3.6$ \\
\hline 1100 & 60 & 13.90 & 99.17 & 4.12 & 0.53 & 3.87 & $54.8 \pm 3.1$ \\
\hline 1150 & 60 & 27.61 & 99.72 & 3.90 & 0.41 & 5.08 & $71.6 \pm 4.6$ \\
\hline 1200 & 60 & 310.76 & 99.86 & 4.10 & 0.62 & 36.43 & $459.9 \pm 39.9$ \\
\hline 1500 & & 1220.10 & 99.99 & & 0.72 & 68.36 & $784.6 \pm 119.2$ \\
\hline
\end{tabular}

* The ${ }^{41} \mathrm{Ar}{ }^{*}$ corresponds to radiogenic argon.

Tibet. Tapponnier et al. and Meyer [Tapponnier et al., 1990b; Meyer, 1991], for instance, have inferred the numerous, parallel active thrusts of the Qilian Shan, on the northeastern edge of Tibet, to root into such a crustal-scale décollement. North of the Lijiang mountains, in the Songpan Garze region (Figure 14a), another large-scale décollement with transport toward the south appears to lie the base of a thick pile of folded Triassic flysch and Paleozoic sediments [Mattauer et al., 1992; Calassou, 1994]. As Upper Triassic granites intrude folds at places, motion on the décollement has been inferred to be mostly Triassic in age [Mattauer et al., 1992]. Ductile shear on this décollement and the associated metamorphism, however, have not yet been dated, and it is plausible that part of the transport occurred during the Tertiary. Farther SE, within Indochina (Figure 14a), a Tertiary phase of $\approx \mathrm{N}-\mathrm{S}$ shortening affects the Khorat Mesozoic series [Mouret, 1994], and possibly also the northwestern mountainous part of Vietnam, where present-day elevations exceed $3000 \mathrm{~m}$ and Cretaceous red beds are commonly folded (Annam, Black-River, and Tonkin ranges). Restoring about $700 \mathrm{~km}$ and $300 \mathrm{~km}$ of leftlateral displacements on the Red River and Xianshui He Fault zones, respectively [Peltzer and Tapponnier, 1988; Yang 


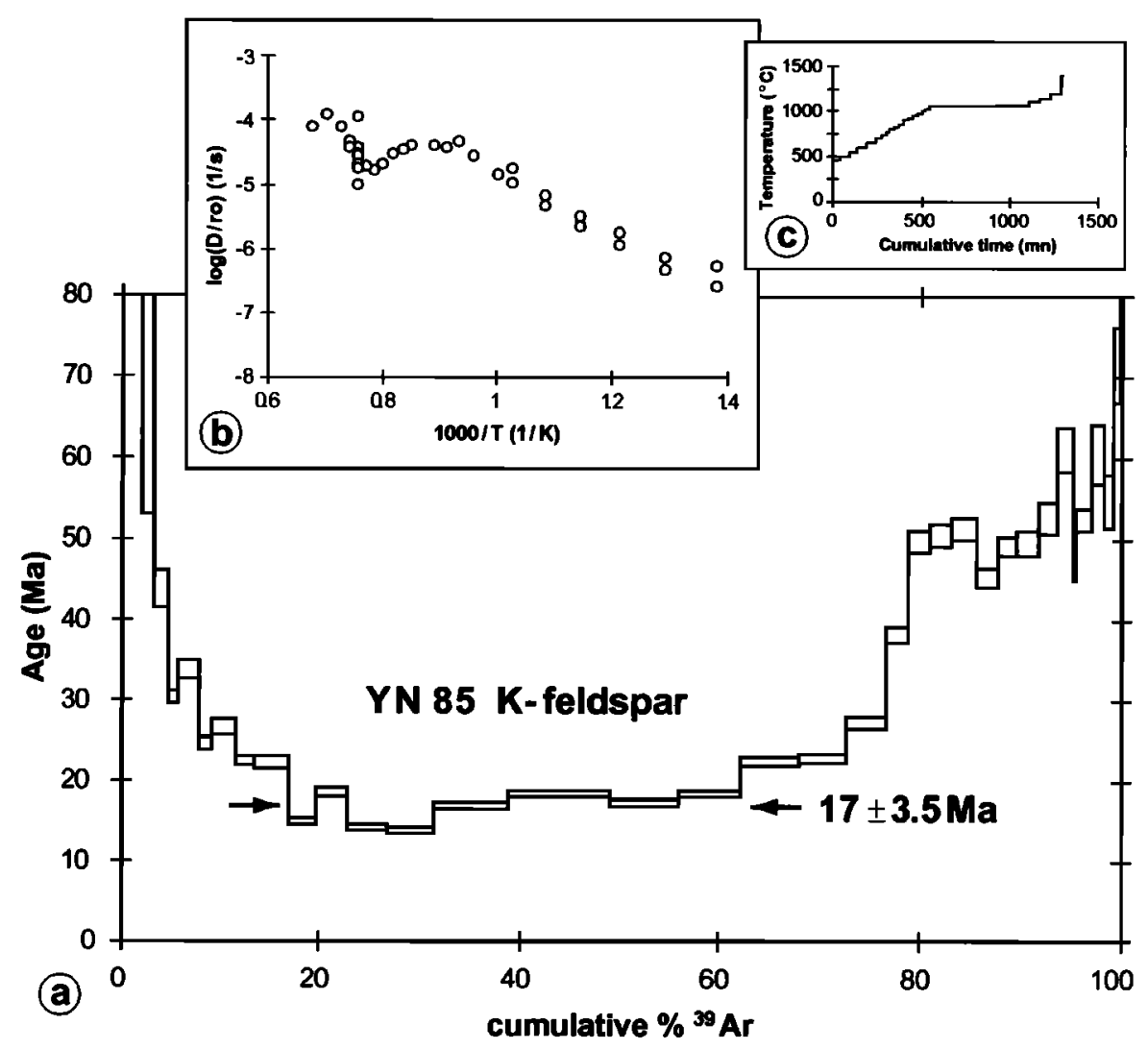

Figure 13. The ${ }^{39} \mathrm{Ar} /{ }^{40} \mathrm{Ar}$ analysis of $\mathrm{K}$-feldspar extracted from sample $\mathrm{YN}-85$ (quartz-feldspar bearing micaschist). (a) Age spectrum. Rough plateau yields age of $17 \pm 3.5 \mathrm{Ma}$ (20 to $68 \%$ of Ar release). Last $20 \%$ of Ar release defines rougher plateau between 48 and $51 \mathrm{Ma}$. (b) Arrhenius diagram. (c) Heating procedure, starting at $450^{\circ} \mathrm{C}$, used for analysis.

Zhenyu and Besse, 1993; Leloup et al., 1995], would place those ranges in rough continuity with the Yulong Shan and Songpan-Garze (Figure 14b). The location of these regions would therefore have been adequate for significant N-S shortening of the Asian crust to occur north and northeast of the Indian front, in the early stages of collision but mostly prior to the onset of Indochina's extrusion (Figures 14a and 14b). Such shortening perhaps reactivated older crustal thrusts and suture zones separating the different blocks of northern Tibet [Sengör and Hsï, 1984]. The reconstruction of figure $14 \mathrm{~b}$ thus implies that a south verging thrust belt existed north and NE of Tibet in the lower-middle Tertiary. The thick unconformable midupper Eocene molasse found at several localities of north western Yunnan, southeastern Sichuan and eastern Tibet [Bureau of Geology and Mineral Resources of Yunnan, 1983; Jiao Shupei et al., 1988; Wang and Chu, 1988; Leloup et al., 1995], and intruded by monzonitic rocks dated at 35Ma near Jianchuan [Schärer et al., 1994], might result from the erosion of the corresponding relief.

For the most part, large-scale sinistral motion on the Ailao Shan-Red River shear zone, dated between $35 \mathrm{Ma}$ and $\approx 17$ Ma [Schärer et al., 1990; Harrison et al., 1992; Leloup et al., 1993; Schärer et al., 1994], appears to postdate this early phase of shortening. As strain became localized along that large strike-slip shear zone, at rapid slip rate $(3-4 \mathrm{~cm} / \mathrm{yr})$
[Leloup et al., 1995], the direction of regional shortening shifted to $\approx \mathrm{E}-\mathrm{W}$, consistent with transpressive folding of the red beds in adjacent basins. This second shortening phase, which is in part coeval with left-lateral movement, is best documented in the red bed basins of Yunnan but is ubiquitous accross both Sundaland and South China (Figure 14a). We infer anticlinal doming of the Yulong Shan to be related to that second phase of Tertiary shortening, as most of the folding of the Mesozoic red beds of the Chuxiong and Simao basins (Figures 12,14a, and 14c). Since antiformal doming of the Yulong Shan postdates transport on the Yulong décollement, the corresponding $\mathrm{E}-\mathrm{W}$ shortening phase must postdate $35 \mathrm{Ma}$. The ${ }^{39} \mathrm{Ar} /{ }^{40} \mathrm{Ar}$ age spectra of $\mathrm{K}$-feldspar would be consistent with cooling, plausibly related to the antiformal uplift, and concurrent denudation by erosion, of the Yulong core, at $\approx 17 \mathrm{Ma}$. The well-preserved antiformal shape and positive relief and the fact that the course of the Jinsha river is antecedent to the growth of that great fold (Figure 12) imply anabated folding well into the late Miocene. Such folding must have ceased before the onset of the current regime of $\approx \mathrm{E}-\mathrm{W}$ extension, around $5 \mathrm{Ma}$ [Leloup et al., 1993], which probably created the recent normal faults bounding the eastern flank of the Yulong Shan (Figure 3 and 4).

Elsewhere [Leloup, 1991; Leloup et al., 1995], we have inferred Tertiary décollements similar to that now exhumed in 

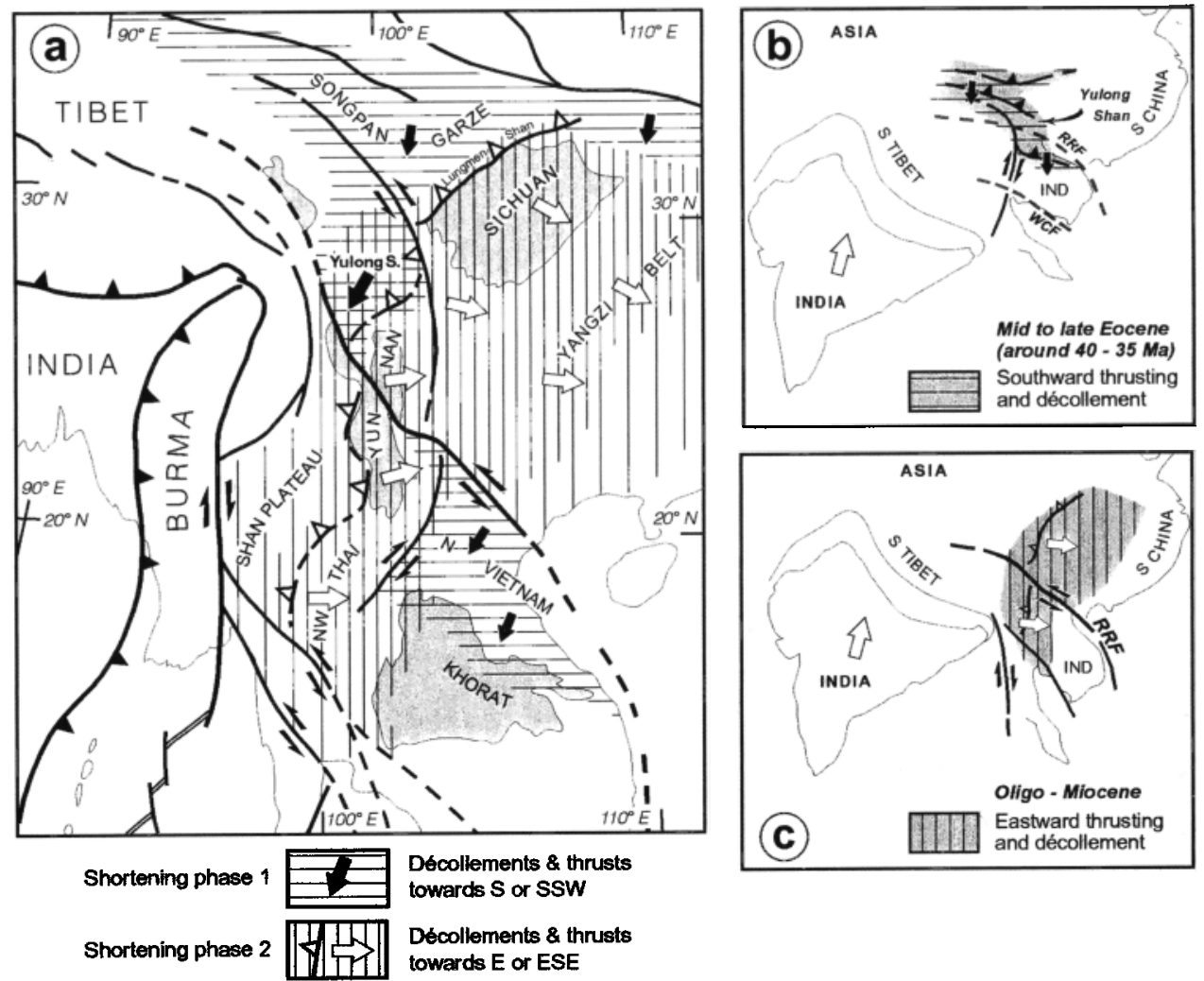

Figure 14. Regions affected by Cenozoic shortening east of Himalayas and Tibet. Décollements, comparable to that exhumed in Yulong Shan, are inferred to underlie fold and thrust belts visible at surface. Motion on décollements was nearly perpendicular to fold axes. (a) Sketch map showing possible extension of, and transport direction on, regional Cenozoic décollements (see discussion in text). Faults with open triangles correspond to probable location of crustal thrust ramps corresponding to phase 2 shortening. (b) Speculative geometry and location of mid to late Eocene décollements and thrusting toward the south in framework of India-Asia collision. Shortening is inferred to have occurred north and northeast of Tibet at this time, possibly in connection with right lateral motion on Dien Bien Phu Fault zone. Abbreviations are RRF, Red River Fault; WCF, Wang Chao Fault; IND, Indochina. (c) Speculative geometry and location of Miocene to Pliocene-Quaternary décollements, underlying folded regions of South China and NW Indochina.

the Yulong Shan, but with transport mostly toward the east, to underlie the Mesozoic sandstones of the Simao, Chuxiong and Sichuan basins and to be structurally related to the roughly $\mathrm{N}$ $S$ anticlines in those basins (Figure 14a). From the inferred 17 Ma uplift age in the Yulong Shan we infer that, at least north of the Ailao Shan-Red River shear-zone, $\approx E-W$ shortening may have accompanied the end of Indochina extrusion.

Shortening and transport toward the east, seem to have taken place over a wide area east of the Tibet and Shan plateaus, encompassing northwestern Thailand in the south and much of the Yangzi platform and Sichuan basin in the north (Figure 13a and c). At the scale of that area $\left(\approx 210^{6}\right.$ $\mathrm{km}^{2}$ ), it seems likely that such shortening was diachronous, possibly in tune with the northward motion of India. It might have occurred earlier in NW Thailand, for instance, coeval with the late stages of sinistral motion on the Wang Chao Fault around 30 Ma [Maluski et al., 1993; and R.Lacassin et al., manuscript in preparation, 1996], than farther north. Roughly E-W shortening still takes place in Sichuan with décollements and ramp thrusts underlying the folded Yangzi belts as well as the Lungmen Shan. Much more chrono logical evidence will be needed to establish the exact timing of crustal shortening phases over such a vast area. Nevertheless, the northward diachronism of the onset of E-W shortening and of east directed transport in regions located on the east side of the Indian indenter seems as inescapable a consequence of the northward penetration of India into Asia, as the successive extrusion of large continental blocks located farther and farther north on that side has proved to be [Tapponnier et al., 1986; Peltzer and Tapponnier, 1988; Lacassin et al., 1995; Leloup et al., 1995]

Acknowledgments. Fieldwork in the Yulong Shan was performed in 1991, during the Hong He - Jinsha Jiang cooperative program between the Centre National de la Recherche Scientifique (CNRS), the National Science Foundation of China, and Academia Sinica. This project was directed in China by Zhong Dalai who is gratefully acknowledged. We thank L. Ratschbacher, P. Copeland and K. Burke for constructive reviews and suggestions. J.R. Kienast helped us to assess the metamorphic grade of the Yulong micaschists. Guy Aveline is responsible for the quality of figures. This is I.P.G.P. contribution 1418. 


\section{References}

Allen, C. R., A. R. Gillespie, Y. Han, K. E. Sieh, B. Zhang, and C. Zhu, Red River and associated faults, Yunnan province, China: Quaternary geology, slip rates, and seısmic hazard, Geol. Soc. Am. Bull. , 95, 686-700, 1984.

Armijo, R, P. Tapponnier, and H. Tonglin, Late Cenozorc right-lateral strike-slip faulting in southern Tibet, $J$. Geophys. Res., 94, 2787-2838, 1989.

Avouac, J.-P., and P. Tapponnier, Kinematic model of active deformation in central Asia, Geophys. Res. Lett., 20, 895-898, 1993.

Berthé, D., P. Choukroune, and D. Gapais, Orientations préférentielles du quartz et orthogneissification progressive en régime cisaillant: L'exemple du cisaillement sudarmoricain, Bull. Minéral., 102, 265-272, 1979a.

Berthé, D., P. Choukroune, and P. Jegouzo, Orthogneiss, mylonite and non-coaxial deformation of granites: The example of the South Armorican shear zone, J. Struct. Geol, , 1, 31-42, 1979b.

Boyer, S. E., and D. Elliott, Thrust systems, AAPG Bull, 66, 1196-1230, 1982.

Briais, A., P. Patriat, and P. Tapponnier, Updated interpretation of magnetic anomalies and seafloor spreading stages in the South China Sea: Implications for the Tertiary tectonics of SE Asia, $J$ Geophys. Res., 98, 6299-6328, 1993.

Bureau of Geology and Mineral Resources of Yunnan, Geological map of Yunnan, scale 1:1,000,000, Kunming, China, 1983.

Calassou, S., Etude Tectonique d'une chaîne de décollement. A - Tectonique Triasique et Tertiaire de la chaîne de Songpan Garze (Est Tibet); B - Géométrie et cinématique des déformations dans les prismes d'accrétion sédimentaires: Modélisation analogique, Ph.D. thesis, 369 pp., Univ. Montpellier II, Montpellier, France, 1994.

England, P., and G. Houseman, Finite strain calculations of continental deformation, 2 , Comparison with the India-Asia collision zone, J. Geophys. Res., 91, 3664-3676, 1986.

England, P., and P. Molnar, Right-lateral shear and rotation as the explanation for strike-slip faulting in eastern Tibet, Nature, 344, 140-142, 1990.

Etchecopar, A., and J. Malavieille, Computer model of pressure shadows: A method for strain measurement and shear-sense determination, J. Struct. Geol. , 9, 667-677, 1987.

Funahara, S., N. Nishiwaki, M. Miki, F. Murata, Y. Otofuji, and Y. Z. Wang, Paleomagnetic study of Cretaceous rocks from the Yangtze block, central Yunnan, China: Implications for the India-Asia collision, Earth Planet. Scı Lett., II3, 77 91, 1992.

Funahara, S., N. Nishiwaki, F. Murata, Y. Otofuji, and Y. Z. Wang, Clockwise rotation of the Red River fault inferred from paleomagnetic study of the Cretaceous rocks in the Shan-Thai-Malay block of eastern Yunnan, China, Earth Planet. Sci. Lett., I17, 29-42, 1993.

Gaudemer, Y., and P. Tapponnier, Ductile and brittle deformations in the northern Snake Range, Nevada, J. Struct. Geol., 9, 159-180, 1987.

Geological Bureau of Yunnan Province, Geological map of Yunnan province, scale 1:500,000, Kunming, China, 1979.

Gu Gongxu, Lin Tinghuang, Shi Zhenliang, Li Qun, Wu Huanying, Lu Shoude, Yang Yulin, Chen Haitong, and Wang Suyun (Eds.), Catalogue of Chinese Earthquakes (1931 B.C. - 1969 A.D.), 872 pp., Sci. Press, Beijing, China, 1989.

Hanmer, S., and C. Passchier, Shear-Sense Indicators: A Review, Paper Geol. Surv. Can., 90-17, 72 pp., 1991.

Harrison, T. M., M. T. Heizler, and O. M Lovera, ${ }^{39} \mathrm{Ar} /{ }^{40} \mathrm{Ar}$ results for alkali feldspar containing diffusion domains with differing activation energy, Geochim. Cosmochim. Acta, 55, 1345-1448, 1991.

Harrison, T. M., Chen Wenji, P. H. Leloup, F. J. Ryerson, and P. Tapponnier, An early Miocene transition in deformation regime within the Red River fault zone, Yunnan, and its significance for Indo-Asian tectonics, J. Geophys. Res, 97, 7159-7182, 1992.

Harrison, T. M., P. H. Leloup, F. J. Ryerson, P. Tapponnier, R. Lacassin, and Chen Wenji, Diachronous initiation of Transtension along the Ailao Shan-Red River Shear zone, Yunnan and Vietnam, in The Tectonics of Asia, edited by T. M. Harrison and An Yin,. in press, Cambridge Univ. Press, New York, 1995.

Huang Kainan, and N. D. Opdyke, Paleomagnetic results from Cretaceous and Jurassic rocks of South and southwest Yunnan: Evidence for large clockwise rotations in the Indochina and Shan-Thai Malay terranes, Earth Planet. Sci. Lett., 117, 507-524, 1993.

Jiao Shupei, Zhang Yifu, Yi Shaoxian, Ai Changxing, Zhao Younian, Li Yaomin, Wang Huaida, Xu Jian'e, Hu Jinqing, and Guo Tieying, Geological map of Qinghai Xijang (Tibet) plateau and adjacent areas, scale 1:1,500,000, Geol. Publ. House, Beijing, China, 1988.

Lacassin, R., and M. Mattauer, Kilometrescale sheath fold at Mattmark and implications for transport direction in the Alps, Nature, 316, 739-742, 1985.

Lacassin, R., P. H. Leloup, and P.
Tapponnier, Bounds on strain in large Tertiary shear zones of SE Asia from boudinage restoration, J. Struct. Geol., 15, 677-692, 1993.

Lacassin, R., $P$ H. Leloup, and P. Tapponnier, Strain localization in time and space during the India-Asia collision (abstract), Terra Nova, 7, suppl. 1, 46, 1995.

Le Pichon, X., M. Fournier, and L. Jolivet, Kinematics, topography, shortening, and extrusion in the India-Eurasia collision, Tectonics, H, 1085-1098, 1992.

Leloup, P. H., Cinématique des déformations "hımalayennes" dans la zone de cisaillement crustale de l'Ailao Shan Fleuve Rouge, Ph.D. thesis, 148 pp., Univ. Paris 6, Paris, February 1991.

Leloup, P. H., T. M. Harrison, F. J. Ryerson, Chen Wenji, L. Qi, P. Tapponnier, and R. Lacassin, Structural, petrological and thermal evolution of a Tertiary ductile strike-slip shear zone, Diancang Shan, Yunnan, J. Geophys. Res., 98, 6715-6743, 1993.

Leloup, P. H., P. H. Tapponner, R. Lacassin, T. M. Harrison, Chen Wenji, and $F$. Ryerson, Diachronic uplift, transtension, and sinistral shear rate along the Red River zone, Eos Trans. AGU, 75 (44), Fall Meet. Suppl., 630, 1994.

Leloup, P. H., R. Lacassin, P. Tapponnier, Zhong Dalai, Liu Xiaohan, Zhang Lianshang, Ji Shaocheng, and Phan Trong Trinh, The Ailao Shan-Red River shear zone (Yunnan, China), Tertiary transform boundary of Indochina, Tectonophysics, 251, 3-84, 1995.

Lovera, O. M., F M. Richter, and T. M. Harrison, Diffusion domains determined by ${ }^{39} \mathrm{Ar}$ released during step heating, $I$ Geophys. Res. , 96, 2057-2069, 1991.

Maluski, H., R. Lacassin, P. H. Leloup, A. Briais, $S$. Bunopas, $C$. Hinthong, and $K$. Siribhakdi, Mid-Oligocene left-lateral shear along the Wang Chao fault zone (NW Thailand) (abstract), Terra Nova, 5 , suppl.. 1, 262, 1993.

Mattauer, M., J. Malavieille, S. Calassou, J. Lancelot, F. Roger, H. Ziwen, X. Zhiqin, and $H$. Liwei, La chaîne Triassique de Songpan-Garze (Ouest Sechuan et Est Tibet): une chaîne de plissementdécollement sur marge passive, $C . R$. Acad. Sci., Ser. II, 314, 619-626, 1992.

Meyer, B., Mécanismes des grands tremblements de terre et du raccourcissement crustal oblique au bord Nord-Est du Tibet, Ph.D. thesis, 129 pp., Univ. Paris 6, Paris, 1991.

Miller, D. S., P. F. Duddy, A. J. Hurford, and C. W. Naeser, Results of interlaboratory comparison of fission-track age standards: 
Fission-Track Workshop-1984, Nucl. Tracks Radiat. Meas., 10, 383-391, 1985.

Mouret, C., Geological history of northeastern Thailand since the Carboniferous. Relations with Indochina and Carboniferous to early Cenozoic evolution model, in Proceedings of the International Symposium on Stratigraphic Correlation of Southeast Asia, edited by P. Angsuwathana et al., pp. 132-158, Dep. of Miner. Res., Bangkok, Thailand, 1994.

Peltzer, G., and P. Tapponnier, Formation and evolution of strike-slip faults, rifts, and basins during India-Asia collision: An experimental approach, J. Geophys. Res., $93,15,085-15,117,1988$.

Schärer, U., P. Tapponnier, R. Lacassin, P. H Leloup, Zhong Dalai, and Ji Shaocheng, Intraplate tectonics in Asia: A precise age for large-scale Miocene movement along the Ailao Shan-Red River shear zone, China, Earth Planet. Sci. Lett., 97, 65-77, 1990.

Schärer, U., Zhang Lian-Sheng, and P. Tapponnier, Duration of strike-slip movements in large shear zones: The Red River belt, China, Earth Planet. Sci. Lett., 126, 379-397, 1994.

Sengör, A. M. C., and K. J. Hsü, The cimmerides of eastern Asia: History of the eastern end of Palaeo-Tethys, Mém. Soc. Géol. Fr., 147, 139-167, 1984.

Steiger, R. H., and E. Jäger, Subcommission on geochronology: Convention on the use of decay constants in geo- and cosmochronology, Earth Planet. Sci. Lett., 36, 359-362, 1977.

Tapponnier, P., and $P$. Molnar, Active faulting and tectonics in China, $I$ Geophys. Res., 82, 2905-2930, 1977.

Tapponnier, P., G. Peltzer, and R. Armijo, On the mechanics of the collision between India and Asia, in Collision Tectonics, edited by M.P. Coward and A. C. Ries, Geol. Soc. Spec. Publ. London, 19, 115 . 157, 1986.

Tapponnier, P., R. Lacassin, P. H. Leloup, U. Schärer, Zhong Dalai, Liu Xiaohan, Ji Shaocheng, Zhang Lianshang, and Zhong Jiayou, The Ailao Shan/red River metamorphic belt: Tertiary left-lateral shear between Indochina and South China, Nature, 343, 431-437, 1990 a.

Tapponnier, P., et al., Active thrusting and folding in the Qi Lian Shan, and decoupling between the upper crust and mantle in northeastern Tibet, Earth Planet. Sci. Lett. , 97, 382-403, 1990 b.

Wang, E., and J. J. Chu, Collision tectonics in the Cenozoic orogenic zone bordering
China, India and Burma, Tectonophysics, 147, 71-84, 1988.

Yang Zhenyu, and J. Besse, Paleomagnetic study of Permian and Mesozoic sedimentary rocks from Northern Thailand supports the extrusion model for Indochina, Earth Planet. Sci. Lett., 117, 525-552, 1993.

N. Amaud, URA 10 CNRS, Magmas et Volcans, Université de Clermont-Ferrand, 5 rue Kessler, 63038 Clermont-Ferrand, France.

R. Lacassin, P.H. Leloup, and P. Tapponnier, Laboratoire de Tectonique, Mécanique de la Lithosphère, URA 1093 CNRS, Institut de Physique du Globe de Paris, 4 place Jussieu, 75252 Paris Cedex 05, France. (e-mail: lacassin @ipgp.jussieu.fr)

$X$. Liu, Institute of Geology, Academia Sinica, B.O. Box 634, Beijing, China.

U. Schärer and L. Zhang, Laboratoire de Géochronologie, URA 1093 CNRS, Université Paris 7 and Institut de Physique du Globe de Paris, 4 place Jussieu, 75252 Paris Cedex 05, France.

(Received June 19, 1995; revised November 30, 1995; accepted December 1, 1995.) 